\title{
History and the Hebrew Bible: Culture, Narrative, and Memory
}

\author{
Ian D. Wilson \\ University of Alberta, Augustana Campus, Alberta, Canada \\ iwilson@ualberta.ca
}

\begin{abstract}
This essay offers an introduction to select disciplinary developments in the study of history and in historical study of the Hebrew Bible. It focuses first and foremost on "cultural history," a broad category defined by nineteenth- and twentieth-century developments in anthropology and sociology, literary theory and linguistics, and other fields of study. The first part of the essay comments on developments since the socalled "linguistic turn," highlighting some key works on culture, narrative, and memory, in order to establish a contemporary historical approach to biblical studies. It then turns to questions of the Hebrew Bible's usefulness for historical study, and highlights studies of King David and the Davidic polity in ancient Israel/Judah, to show how scholars of the Bible have done historical work in recent years. And finally, it provides a case study of the book of Joshua, demonstrating how historians can utilize biblical texts as sources for cultural history.
\end{abstract}

\section{Keywords}

historiography - empiricism - linguistic turn - anthropology - narratology - social memory - Israel - Judah - King David - Book of Joshua

\section{Introduction}

Contemporary study of the Hebrew Bible rests upon methodological foundations laid during the eighteenth, nineteenth, and twentieth centuries, methods that were "largely concerned with the history of the text and of the cultures that produced the texts" (Newsom 2010: 2227). In the "post-Enlightenment 
mood of the emerging third millennium" (Nissinen 2009: 479), however, Hebrew Bible research has, to some extent, broken away from its historical foundations. A number of critical methodologies that are not historical per se have developed and thrived in recent decades, including various forms of ideological criticism, modern and postmodern literary criticisms, and even so-called postcritical perspectives. Yet many of these studies remain interested in history in one way or another; they remain devoted to issues concerning the past and its perceived differences, though they ask different sorts of questions than the historically inclined scholars of previous generations. And even those criticisms that self-identify as somehow non-historical have consistently identified themselves vis-à-vis historical criticism, their "mutual intellectual adversary" (Newsom 2009: 557; cf. Nandy 1997: 50). Thus, historical study remains thoroughly in the mix, even as it becomes more and more diffuse within biblical studies generally, in the twenty-first century.

In our ongoing historical age, then, what are scholars saying about history and the Hebrew Bible? In recent decades, what have been some major trends in historical work in general, and how have these trends impacted biblical scholarship? Herein I offer an introduction to select disciplinary developments along with some thoughts of my own. I begin the essay with a discussion of some trends in the study of history, focusing mainly on what might be called "cultural history": a broad and unwieldy category, the boundaries of which are fuzzily defined by nineteenth- and twentieth-century developments in anthropology and sociology, literary theory and linguistics, along with other fields of study (Burke 2008). In this first part of my essay, I comment on several developments since the so-called "linguistic turn" in the late twentieth century, highlighting some key works on culture, narrative, and memory, in order to establish my own approach to biblical studies. The essay then turns, in its second part, to the Hebrew Bible and contemporary historical work in that field. What are some of the major debates of recent years, and what kind of work has developed from these debates? In my attempt to answer these questions, I focus first and foremost on the history of Israel's early monarchy, on David and the Davidic polity, reviewing several recent scholarly efforts that exemplify current biblical studies of this subject, and paying special attention to how these works relate to the aforementioned trends in historical inquiry. For David and his dynasty, there are trace amounts of extra-biblical evidence that can supplement one's discussion of Israel's early monarchic period, and current historical scholarship has grown increasingly sophisticated in its understandings of the matrix of archaeological, epigraphic, and biblical data. For much of the Bible's content, however, relevant historical data does not exist beyond the biblical narrative itself. What can one do, historically speaking, with regard to a text 
like the book of Joshua or Judges, for example? I argue that cultural history, especially cultural history that delves into issues of narrative and social memory, is well suited for doing historical work with this kind of text.

Finally, in part three, therefore, I present a brief inquiry of my own concerning the book of Joshua. My comments on Joshua do not attempt to solve any specific historical problem vis-à-vis this biblical book. Their goal, instead, is to demonstrate what a historically informed approach to this ancient Judean literary artifact might look like, today, in light of our lack of extra-biblical data to work with, and in light of the theoretical and methodological issues raised throughout the essay. In the end, my work here offers one take, a perspective as it were, on historical and biblical studies. It makes no claim to present a comprehensive overview of historical theory and method in general and Hebrew Bible studies in particular, if that were even possible. There are many scholarly issues and efforts that, unfortunately, I cannot address here. What follows is one scholar's impression, so to speak, an indication of some important ways that history has been done in recent years, and how historical work has marked — and can continue to be important for — the study of biblical texts.

\section{Part 1: History and Culture, Narrative, Memory}

All critiques of history from within the modern worldview have also been ultimately historical.

NANDY 1997: $5^{0}$

Over the course of the previous two hundred years, empiricism predominated over historical inquiry; it was the major theoretical and methodological foundation for the modern discipline of history (Green and Troup 1999: 1-11; Mazlish 2003). Attempting to recount the past objectively and neutrally, "how it actually happened" (wie es eigentlich gewesen), ${ }^{1}$ modern scholarship tended

1 The famous phrase of German historian Leopold von Ranke, published in 1824, in the preface to his Geschichten der romanischen und germanischen Völker (available, in the original German and in English translation, in the German History in Documents and Images [GHDI] collection, online: http://germanhistorydocs.ghi-dc.org/sub_document.cfm?document_id= 358; accessed 7 June 2017). By famously claiming that he sought only to reveal the past wie es eigentlich gewesen, Ranke wanted to avoid making historical judgments; ostensibly, he was not interested in shaping present and future concerns. At least for late nineteenth- and early twentieth-century American historians, then, he was a "mythic hero ... empirical science incarnate" (Novick 1988: 28). Still, Ranke believed history to be, in some way, "the working out of God's will" (Green and Troup 1999: 2) - a belief revealed in the same book preface, where he claims that history writing should, ideally, "deal with humanity as it is, explicable or 
to prefer histories that relied mainly, if not exclusively, upon the examination of primary sources of evidence. Within the dominant empiricist framework, history and its composition rested first and foremost upon the conviction that the past is a knowable reality, and that certain sources can provide observable and verifiable knowledge of that past reality. ${ }^{2}$

Bolstering this dominant framework was an understanding that empirical knowledge had somehow always been essential to "proper" historical thought. Although empiricism as such did not develop fully as an epistemology until the modern era, its principles - some would argue - were evident already in ancient, classical historical writing. Thucydides, for instance, who wrote in the late fifth century $\mathrm{BCE}$, claimed to rely on what we might call empirical data in his History of the Peloponnesian War (e.g., 1.20-22), and so, in the early twentieth century CE, the ancient Greek historian became something of an icon of professional historical (and even scientific) inquiry (e.g., Cochrane 1929). More recently, scholars have argued - and I agree - that Thucydides' quasiempiricism was blown out of proportion in one way or another, thus diluting his import as a thinker and writer in his context and for our own (Workman 2015; Forsdyke 2017). But the ancient historian's occasional remarks on method nonetheless left their mark on the contemporary discipline of history, providing a classical justification for a modern empiricist approach. Empiricism thus stood, for much of the modern era, as the preferred theory of historical knowledge, and investigation of empirical data-i.e., directly observable and verifiable documents and artifacts—-served as the methodological benchmark for historical study.

During the latter half of the twentieth century, however, the dominance of historical empiricism began to wane. To be sure, empirical evidence remained (and remains) a key component of historical method—one would be hard pressed to find a historian who denies the import of such evidence-but as an epistemology of history its stature has diminished on account of sustained

inexplicable; the life of the individual, of generations, of nations; and, at times, with the hand of God above them." How to understand Ranke's religiosity and his interest in "the hand of God" in history is a point of debate in studies of his work (e.g., Braw 2007). On Ranke's legacy in general, see Iggers and Powell 1990.

2 E.g., Arnaldo Momigliano (2016 [Italian original, 1975]), once wryly commented, "The historian works on the assumption that it is possible to reconstruct and understand the facts of the past. If an epistemologist succeeds in convincing him of the contrary, the historian will have to take up some other line of work" (40), and further, "All of a historian's work is devoted to sources.... What ultimately makes a historian is the ability to read the document [i.e., a source] as if it were not a document, but an actual event of past life" (45). 
critique (Green and Troup 1999: 1; Mazlish 2003: 13; Clark 2004: 9-28). ${ }^{3}$ This critique stemmed largely from the so-called "linguistic turn" in the humanities (Rorty 1992), a turn more or less coterminous with structuralist and eventually poststructuralist and postmodernist thought. ${ }^{4}$ As Gabrielle Spiegel (2005) describes it, the linguistic turn refers to "the notion that language is the constitutive agent of human consciousness and the social production of meaning, and that our apprehension of the world, both past and present, arrives only through the lens of language's precoded perceptions" (2). The notion that languages have inherent structures of meaning, and that these structures constitute our social, cultural, and historical experience, stems from the early twentieth-century works of Swiss linguist Ferdinand de Saussure and American philosopher Charles Sanders Peirce on sign systems or "semiotics" (Chandler 2007; Aichele 2016: 5-14). This notion has had a profound impact on the humanities generally and on understandings of history in particular. Very simply put, if language has inherent systems of meaning that construct reality, and not vice versa, then the concept of history as the real past—and as a mediation between reality past and present—becomes problematic. According to this line of thought, if taken to its most extreme possible outcome, history no longer deals with any real past, or with primary sources that provide some amount of present access to past reality; it deals with, instead, traces of linguistic structures that are encountered via other, different linguistic structures. Indeed, from this point of view, there would be no such thing as a past reality with connections to the present; in other words, "the idea of an objective

3 This is not to say, however, that empiricism is dead in history. See, e.g., Jeremey Black (2015), a prolific British historian who deems empiricism and objectivity necessary to make history publically and politically relevant today.

4 Poststructuralist/postmodernist thinking, typically associated with the likes of Michel Foucault, Jacques Derrida, and other French philosophes of the late twentieth century, has played a considerable role in historical study during the last fifty years or so, though mostly in discussions of theory and less so in methodological practice (Green and Troup 1999: 297-307). Foucault has been especially influential (and controversial) among historians (see, e.g., O'Brien 1989; Goldstein 1994). That said, in this essay I do not discuss Foucault in detail, for several reasons. One is that, despite his undeniable impact on discussions of historical theory and historical subject matter, Foucault's actual influence in the disciplinary work of history, even at the cutting-edge of such work, has been somewhat limited (Megill 1987; cf. Partner 2016: 47). In addition, as Kerwin Lee Klein (2011: 59-83) argues, for historians in North America at least, the advent of the linguistic turn and the reception of French poststructuralism was primed already by developments in Anglophone anthropology, ethnography, and philosophy. In my discussion below, therefore, I focus on other thinkers and their influences on history, but without denying the import of Foucault and likeminded scholars of his generation. 
universe existing independently of speech and universally comprehensible despite one's membership in any particular language system is an illusion" (Spiegel 2005: 2).

Many current historians, while recognizing and even drawing on the insights of the linguistic turn, have not followed the turn to its most drastic possible outcome. Historians, along with anthropologists, sociologists, and the like, have consistently tempered the more extreme possibilities of (post)structural linguistics and philosophy with an understanding that there are, in fact, historical actors with agency in actual social contexts. Language may construct our reality, at least to some extent, but we nonetheless consciously use and thus shape language structures within human society. Linguistic structures are not static, closed systems. They are dependent, in part, on their dynamic and ongoing usage among historical actors (cf. Spiegel 2005). This recognition has enabled the work of history to continue and even thrive, albeit in ways radically different from the work of the nineteenth- and early twentieth-century empiricists, and in ways diverse as ever.

\section{$1 \quad$ Cultural Theory and Fragmentation in History}

The linguistic turn challenged the epistemological foundations of historical study in the modern era, but it also reoriented historical concerns. The issue of language's relation to meaning-production is obviously relevant to many disciplines in the humanities and social sciences. And so the increased focus on this issue across the academy led to an increase in cross-disciplinary interaction and influence. Developments in the fields of anthropology and ethnography in particular-developments that had close ties to the linguistic turn's intellectual movements-have had a profound impact on the work of historians, and developments in historical theory, in turn, have shaped anthropological thought. Over the course of the twentieth century, many historians turned away from typical investigations of political regimes and revolutions, wars and "great men" and so on, and toward questions of culture. How and why humans interact and communicate, within and between societies, and what meanings are produced through such interactions - the kinds of questions also asked by field-working anthropologists_-became major talking points in the discipline of history.

In the latter half of the twentieth century, especially in Anglophone contexts, the anthropological work that was most influential in the study of history was Clifford Geertz's The Interpretation of Cultures. ${ }^{5}$ The book, published in

5 Other mid to late twentieth-century anthropologists had noteworthy impacts on historical study and should be mentioned here (e.g., Douglas 2002 [original, 1966]; Turner 1969; Sahlins 
1973 and consisting mostly of essays composed in the 1960s, suggested a move toward reading cultures as texts, and texts as cultures. This move was dependent, first and foremost, upon Geertz's conceptualization of culture as semiotic, that is, as a symbolic system. For Geertz, culture is more than the things people make and use, more than the languages they speak, the institutions in which they work and serve and so on. Culture is the interrelated systems of meaning produced by those various aspects of human life, in a social setting. And the anthropologist's job, according to Geertz, is to describe those systems of meaning. It is not enough to describe, say, a person in an expensive downtown coffee shop using a laptop computer with a glowing piece of fruit on it (to imagine a situation an ethnographer might document today); a good anthropologist will, instead, explicate how and why that person's computer brand means something to different persons in that particular situation and time. The anthropologist thus reads and interprets the scene, as the literary critic similarly reads and interprets a written text. What might that little glowing apple communicate about socio-economic standing or the import of personal aesthetics, for instance, to onlookers in the coffee shop, and how might these communications influence social interactions at the shop? What meanings are there in this social scene, how might they relate to other, similar scenarios in the society, and how might all of this operate in concert to drive social life? Geertz called this ethnographic work "thick description" (1973: 3-30), a term he borrowed from philosopher Gilbert Ryle, and he demonstrated it perhaps most famously in an essay about cockfighting in Bali (1973: 412-53). In this kind of work, Geertz argued, the task is "to uncover the conceptual structures that inform our subjects' acts ... and to construct a system of analysis in whose terms what is generic to those structures, what belongs to them because they are what they are, will stand out against the other determinants of human behavior" (27).

This development in anthropological theory and method had considerable influence in the academy at large in the 1980 s and later. Its influence was so widespread that Victoria Bonnell and Lynn Hunt (1999: 2-4), in an important and widely read volume of essays, proclaimed Geertz's Interpretation of Cultures as one of the two most influential books for the social sciences during the closing decades of the twentieth century. ${ }^{6}$ For historians in particular,

1985). But I emphasize Geertz above all, as an exemplar of this trend, because of his undeniably broad influence in history as well as in many other academic disciplines in North America.

6 The other being Hayden White's Metahistory (1973), which I discuss below. Bonnell and Hunt were not alone in their proclamation. The American Sociological Association also included Geertz in its 1996 list of "ten most influential books of the past twenty-five years" (cited in 
Interpretation of Cultures afforded a novel and productive approach to reading sources: following the ethnographic approach championed by Geertz, historians could interrogate their documents with an eye toward culture and cultural systems in order to explicate past phenomena (Biersack 1989). Via Geertz, scholars found a way to examine afresh "who people think they are, what they think they are doing, and to what end they think they are doing it" in certain social-historical contexts (Geertz 2000: 16).

Geertz's approach to cultural anthropology blended philosophical insights from linguistics with ethnographic considerations of actual social life. His work thus provided a new theoretical frame that was akin to the linguistic turn in general, but that also lent itself well to specific historical interests rooted in empirical data. Moreover, while culture-or at least the Geertzian understanding of it - was emerging as a viable and invigorating explanatory concept for history, a number of prominent Marxist historians, as well as adherents to the widely influential Annales "school," were growing increasingly dissatisfied with the limitations of their own standard social-theoretical frameworks (Hunt 1989: 11-14; Spiegel 2005: 7-9). ${ }^{7}$ These growing theoretical dissatisfactions among historians provided further impetus for taking up cultural theory in the 1980 s and later.

For many, then, culture became the new preferred basis for historical analysis, pushing aside old standards like class, economy, government, and other bedrocks that had previously been foundational for inquiries in history. The rise of culture as theoretical key inspired historical luminaries such as Natalie Zemon Davis and Robert Darnton, each of whom collaborated with Geertz in Princeton (Biersack 1989: 76), and whose works emphasize explication of motivations and meanings in local and particular, "ordinary" social contexts of the past (e.g., Davis 1983; Darnton 1984). Concomitantly, as this newly found theoretical key made anthropology more textual and history more anthropological, it likewise made literary studies more historical. The new cultural history of the 1980 os and gos found something of a strange bedfellow in what came to be known as "New Historicism" in literary theory (Veeser 1989; Gallagher and Greenblatt 2000) — with Stephen Greenblatt's Marvelous Possessions (1992), a study of European colonialism via its representation in colonialist anecdotes, standing as New Historicism's parade example. The cultural

Bonnell and Hunt 1999: 4). And Klein (2011) has quipped that "thick description became almost an academic bumper-sticker in the eighties" (64; italics in the original).

7 For overviews of Marxist and Annales histories, see Green and Troup 1999: 33-43 and 87-97, respectively, with many additional references therein. On Marx's legacy in history, see Adamson 2002. On the influence and eventual fragmentation of Annales as a coherent program or "paradigm" for history, see Hunt 1986; and Megill 2007: 190-202. 
history that emerged in the 1980 s and thereafter and the New Historicist literary criticism are often mentioned in the same breath (e.g., Klein 2011: 85-86), and indeed their highest profile practitioners have frequently crossed paths and even collaborated directly. ${ }^{8}$ Thus, for a number of influential scholars in the late twentieth century, the boundary lines between traditional disciplines in the humanities and social sciences became increasingly blurry. As the new millennium approached, anthropologists were thinking more about texts, historians wrote increasingly thick descriptions of past human moments, and scholars of literature were "[probing] the delicate semiosis of history, culture, and power" (Klancher 1989: 77).

In Hebrew Bible studies, the impact of these cross and interdisciplinary developments in cultural theory has been clearly visible. Steven Tuell (1992), for example, drew on Geertz's cultural anthropology to illuminate a social setting for the temple vision in Ezek 40-48. Similarly, E. Theodore Mullen Jr. (1993) took an interpretive-cultural approach in his historical investigation of Deuteronomistic literature, relying on a range of works by prominent cultural theorists. And Amélie Kuhrt, in her widely read history of the ancient Near East (1995), emphasized the cultural function of biblical accounts of Israelite origins (437). The so-called New Historicism, too, with its pronounced interest in Geertzian interpretive-cultural theory, has been prominent in biblical studies since the 1990s (e.g., Rowlett 1996; Hens-Piazza 2002; George 2009). Indeed, in 1997 Biblical Interpretation devoted an entire issue to New Historicism and its various critical stances. In that journal, Robert Carroll (1997) called for a "cultural poetics" of the Hebrew Bible, one concerned with "the historicity of texts and the textuality of history" (301, citing Louis Montrose). Culture thus became a productive theoretical key for scholars interrogating the Bible for insights into ancient Israel and Judah, just as it did for scholars interrogating, for instance, literary and archival documents for insights into early modern European society.

As one might anticipate, however, debate emerged in the academy over the meaning of culture itself. In an essay seminal for historians, William H.

8 An exemplar is the University of California Berkeley journal Representations, the editorial board of which has included new historicists, cultural historians, and symbolic anthropologists alike. See the Introduction in Gallagher and Greenblatt 2000, for an account of the journal's beginnings and interests. That said, as my friend and colleague Andrew Gow has reminded me, it is important to note that not all cultural historians felt (or feel) comfortable associating with New Historicism. As its own disciplinary and methodological movement, New Historicism was reacting to and interacting with problems particular to the world of literary criticism. The interests of New Historicism thus frequently differ from the typical interests of historians (cf. Maza 2004). 
Sewell Jr. (1999), for example, sought to clarify the important distinction between "culture as theoretical category and culture as concrete and bounded body of beliefs and practices" (39). Concerning theory, Sewell maintained a basically semiotic understanding of culture — that is, culture refers to symbolic meaning-making in social life-but he also criticized a tendency to reduce culture to a static system inherent to human society (cf. Biersack 1989: 80). He argued for a semiotic theory of culture that nonetheless took seriously human practice and performance, how humans manufacture and employ meaningsi.e., produce or construct culture-in a given social setting. "[T] he conception of culture as semiotic," wrote Sewell:

implies a particular notion of cultural practice. To engage in cultural practice is to make use of a semiotic code to do something in the world. People who are members of a semiotic community are capable not only of recognizing statements made in a semiotic code ... but of using the code as well, of putting it into practice. To use a code means to attach abstractly available symbols to concrete things or circumstances and thereby to posit something about them. I would also argue that to be able to use a code means more than being able to apply it mechanically in stereotyped situations - it also means having the ability to elaborate it, to modify or adapt its rules to novel circumstances.

SEWELL 1999: 51

This theoretical reformulation, he contended, would better enable historians to understand various human cultures (note the plural), their dynamic histories and interrelationships, "to discern what the shapes and consistencies of local meanings actually are and to determine how, why, and to what extent they hang together" (58).

In an essay complementary to Sewell's, Richard Biernacki (1999) criticized Geertzian cultural histories for tending to essentialize culture and for frequently sidelining or subverting other explanatory concepts that could readily contribute to our understandings of the construction of social reality. ${ }^{9}$ In doing so, he argued, such cultural historians inadvertently made

9 This essentializing tendency was perhaps due to highly selective readings of Geertz. Biernacki (1999), for one, called out proponents of cultural history for "[overusing] bits of Clifford Geertz's philosophical magic" and for "[accepting without argument] spellbinding features" of his work (63). Indeed, typical recitations of Geertz and Geertz's influence on history mention his seminal essays in Interpretation of Cultures, as I myself have done above, but rarely engage his thoughts beyond that volume (one notable exception is Biersack 1989). Very seldom does one find references, for instance, to Geertz's own attempt at historical inquiry, 
the same reductionist move for which they criticized their social-historical predecessors-Marxist, Annaliste, and otherwise (cf. Megill 2007: 203-204). These kinds of critiques have led historians, in recent years, to supplement their focus on culture with additional attention to practice, performance, and human agency within various spheres of social life, in order to develop a more dynamic and multi-dimensional understanding of historical processes (cf. Ortner 1997: 6-11; Spiegel 2005: 22-26). An outstanding exemplar is Biernacki's own work on nineteenth-century weaving mills in Britain and Germany, in which he shows how different measurement practices-represented in written reports, posted on factory walls-effected different labor experiences for

Negara (1980), which includes a short, introductory treatise on historical method, or to his later reflection on the interrelationship of anthropology and history (2000: 118-33; originally published in the journal New Literary History in 1990).

Furthermore, the essentializing tendency gave the impression that history needed to be completely retooled in relation to culture; i.e., that history, as it were, was now obsolete and that something novel and cultural should arise in its place- -hence the "new" historians, "new" historicisms, and so on. But this notion was (and is) largely unfounded. As Biernacki (1999) emphasized, Geertz had an "exhilarating agenda for studying how culture works" (63; italics in the original), and this agenda was not to be dismissed out of hand, by historians or anyone working in the social sciences or humanities for that matter. The problem historians faced was how to integrate Geertz's agenda for studying culture into their own discipline, which — unlike Geertz's primary task of ethnography — attends to the realities of, and explanations for, past social contexts, not the recordable activities of contemporary ones. There is a fundamental tension between "looking back" (i.e., history) and "looking sideways" (i.e., anthropology), and between conceptions of self and other in each discipline, as Geertz himself has put it (2000: 120-21). And, despite numerous attempts, scholars have not been able to overcome this tension in any way that would suggest a new, coherent disciplinary formation. "[T] he conjoining of History and Anthropology is not a matter of fusing two academic fields into a new Something-or-Other, but of redefining them in terms of one another by managing their relations within the bounds of a particular study" (Geertz 2000: 127). The problem is, of course, noticeable in Geertz's own historical work, in which he acknowledges and discusses some of the challenges of fusing disciplinary interests. In Negara, Geertz wants to lay groundwork for a cultural history of state formation in Indic-era (i.e., late first-/early second-millennium CE) Indonesia, broadly speaking, but is forced to base his study on ethnographic data from nineteenth- and twentieth-century Bali, because relevant information for earlier periods is simply too scattered, too fragmentary and ambiguous. With political theater and its cultural import as his foci, he uses recent Balinese data to formulate hypotheses about earlier and broader sociocultural processes, in order to build a base model of the Balinese state from which one could make Weberian ideal-typical and other sorts of comparisons and tease out historical implications. His study, then, provides a blurry freeze-frame of an anthropological concept or, better, a constellation of concepts in relation to classical Indonesian polity, and in doing so it duly recognizes the challenges (perhaps even impossibility) of detailed history-writing on this issue and era. It is an excellent example of how one can draw on both historical and anthropological interests to study and write about the past, but it did not inaugurate a new disciplinary standard or "paradigm" per se (see more below). 
the workers in each respective setting (2005: 236-39; cf. 1995: 41-92). In other words, although the cultural systems were comparable (accounts of cloth production represented by written postings on factory walls), experience of the culture depended upon specific practices within each social setting. In this case at least, practice apparently informed culture, thus complicating any claim that an overarching cultural system was the primary meaning-maker within particular social contexts. This kind of work can be important for biblical studies too. For scholars of the Hebrew Bible who are interested in scribal culture in the ancient Near East, for example, Biernacki's attention to practical differences is instructive. Different practices of writing in certain locales would contribute to the formation of significantly different scribal cultures across the region (cf. Hobson 2012).

Despite these constructive critiques in the 1990s and 2000s, the debates over culture have never really settled. History in the early twenty-first century is a discipline as fragmented and complex as ever. One might argue, as Lynn Hunt (2014) does in her recent survey of the field, that current historians face a paradigmatic crisis of sorts. Cultural theory, she contends, has successfully undermined the old schools of Marxism, modernization, Annales, and identity politics (13-19); but hopes for a new historical paradigm founded on culture never materialized $\left(3^{2-40}\right)$. Therefore Hunt, previously a major champion of theory-inspired cultural history in the 1980 os and gos, now-once againcalls for a new paradigm, one that takes into account both the general and the particular; the global, the local, and even the self. She wants histories that "[pay] attention to changing cultural contexts and the way they are shaped by individual wishes" (131), and prefers historical explanation that "combines psychological and social, intra-European and global factors and that privileges no single one of them" (150). Hunt's taking stock of the culture debates and their outcomes is insightful, and her call for a historical focus on selves and societies in light of globalization is timely. ${ }^{10}$ It is questionable, though, whether history is in need of a new paradigm, or paradigms at all for that matter (a question she recognizes, but dismisses; 40). The idea of a coherent, overarching paradigm perhaps works in relation to the natural sciences-although it has not been without controversy ${ }^{11} \_$but in history it may well be counterproductive. To

10 Cf. Ortner 1997: 7-8, with regard to globalization and anthropological work specifically; see also the collection of articles in History and Theory, Special Issue 54 (2015), which addresses the topic "History and Theory in a Global Frame."

11 The concept of research paradigms and paradigm shifts, of course, comes from the work of Thomas Kuhn (1996 [original, 1962]), who had a tendency "[to coin] terms for speed-readers to abuse” (Geertz 1983: 152). On Kuhn's impact see, e.g., Zammito 2004, also Gutting 2007. 
insist on a paradigm, as it were, would be to limit the critical process in history. Moreover, as one reviewer of Hunt points out, questioning the relationship between self and society has always been central to social and cultural theory, and thus it is doubtful that her suggested approach would constitute anything like a new paradigm (Moyn 2015: 30).

In these past few decades the emphasis on culture and the debates it has caused, I would argue, have greatly enriched the work of history, despite the resultant fragmentation and complexity in the discipline. Instead of somehow inhibiting history or, worse, fully disabling it, cultural theory has enlivened and advanced its study (cf. Bynum 2009: 75-77). Pace Hunt, rather than successfully undermining the older social-historical frameworks of Marxism, Annales, and so on, the retooling of culture has had, more often than not, a rehabilitative effect in various realms of historical inquiry. It has allowed for and contributed to, for example, Natalie Zernon Davis's eloquent reexamination of the age-old debate over religion and capitalism's interrelationship (1997), and Sheldon Pollock's sweeping study of literary culture in India (2006); as well as, more recently, Aziz al-Azmeh's thoroughgoing treatise of Islam's historical emergence (2014) - among other brilliant works that seriously take into account various and dynamic historical conditions, be they political, ecological, psychological, cultural, or something other, to elucidate our knowledge of and thinking about things past.

For scholars of the Hebrew Bible, these developments in cultural theory and the resultant diffusion of historical concerns have opened up new avenues of thought that can help us move beyond the old and well-worn questions of our field. The focus on culture in history pushes us to ask not only how the Bible's texts came together, but also why the complex compositions would have had meaning, and what kinds of meaning they would have had, in their ancient social contexts. It pushes us, too, to question our long-held assumptions about the relationships between social actors and activities in the ancient Near East. What "webs of significance" (Geertz 1973: 5) were spun between literati and politics, priests and economies, kings and theologies, and so on, in different contexts, and how do the texts speak to or reflect such systems of meaning?

Thus, I concur with Allen Megill (2007), who writes, "[P]art of the function of historical study is to shuffle the cards, showing the various ways in which the past is actually incoherent with itself and with our expectations of it, and also showing how the study of the past relies on conflicting modes of understanding and engagement" (207; cf. Eley 2005: 54). The current diffusion of approaches in history, created in large part by the impact of cultural theory in the aftermath of the linguistic turn, provides a fertile setting for new historical work in our era. 


\section{$2 \quad$ Narrative in History}

While the academy at large was turning toward questions of language and the construction of meaning through language, and history was developing a working interest in the concept of culture in relation to society, there was also a boom in discussions about narrative. It is widely regarded that narrative - and especially the act of narrativizing, of crafting and telling a story - is a key component of human thought. "[N]arrative ... includes an entire range of discourse that goes back to the earliest times. People have always told stories"; thus it is an "inexhaustible treasure" that discloses "deep connections to life, to other people, and to society as a whole," as the philosopher Paul Ricoeur once stated in an interview about his work on the topic (in Dowling 2011: 109). Telling stories - that is, crafting narratives - contributes to the construction of both personal and group identities. We do it all the time. Indeed, the concept of identity construction itself may be defined as an ongoing process of crafting and re-crafting narratives about ourselves in relation to others (cf. Bruner 1990: 111-16; Olick and Robbins 1998: 122). Narrative is thus ubiquitous and inescapable in human life, and it is complex. The process of narrativizing, of crafting a story, involves defining a beginning and end, ordering a chronology, choosing particular details to emphasize and deemphasize (or simply leave out), providing syllogistic reasoning of causation (i.e., giving it all a plot), and engaging a range of related ideas in the process. And this process is informed by both conscious and unconscious decisions made by the storyteller (cf. Rigney 2013: 189).

Thinking in part about the construction of narrative, its various forms and complexities, the intellectual historian Hayden White wrote a monumental book called Metahistory: The Historical Imagination in Nineteenth-Century Europe. The book appeared in 1973 - the same year as Clifford Geertz's influential collection of essays on culture. ${ }^{12}$ In it, White did with history-writingi.e., historiography — something similar to what Geertz did with ethnography: he focused on the fact of writing and its inherent processes. Historiography, like ethnography, is composed by the scholar; the historian tells history, thus

12 Below I focus almost exclusively on White as an exemplar of narrative theory's influence in historical work (as I did with Geertz and cultural theory). But other important scholars should be noted here too, such as Frank Ankersmit, Hans Kellner, and Dominick LaCapra (see, e.g., Kramer 1989, on LaCapra as compared to White). The decision to focus mainly on White is practical - there is simply too much to say about this topic—but it is also on account of the fact that White's work, like Geertz's, has had a much broader reach within the humanities than any of his comrades' contributions. In addition, Ankersmit et al. would agree that White's work is fundamental here (cf. Allan Megill, in Domańska 1998a: 4). 
constituting it and imbuing it with certain details and interests and concerns. History is always mediated, brought into the present via the mind and work of the scholar conveying it. Recognizing this, White was interested in examining how historians told their histories, and what the act of narrativizing history might say about historiographical discourse in general. In his study, he read several prominent pieces of history-writing and philosophy from the nineteenth century (namely, works by Hegel, Michelet, Ranke, Tocqueville, Burckhardt, Marx, Nietzsche, and Croce) as sources for the thought patterns and narrative techniques of their authors. White's study was thoroughly unconventional, for a historian. Instead of relying on standard methodological treatises from the field of history, for instance, he utilized theories of plot structure borrowed from the field of literary criticism. ${ }^{13}$ His approach was to examine historians' preferred emplotments and modes of argumentation, their apparent worldviews as well as the ideological implications inherent in certain combinations of plot and argument, in order to reveal nineteenth-century preconceptions about historical reality (i.e., the "tropes" in which these authors thought about the past). The book has been called a "myth" and a "cult book' of theory" (Domańska 1998b: 174). It is a kind of cultural history of history.

White's analysis of nineteenth-century European historiography and philosophy revealed a range of preconceptions about representing the past, in that era and place. He categorized these preconceptions into four separate tropes: Metaphor, Metonymy, Synecdoche, and Irony; and, despite his later claims to the contrary, he suggested that they informed a theory of historical thought and the writing of history (White 1973: 31-38). ${ }^{14}$ The first three tropes, White contends, remain at least somewhat committed to the idea that the historian can figuratively represent past realities; while the last (Irony) reverses this idea by presupposing that a reader or hearer of history will recognize "the problematical nature of language" and "the potential foolishness of all linguistic characterizations of reality" (White 1973: 37). In short, White states, "Metaphor is essentially representational, Metonymy is reductionist, Synecdoche is integrative, and Irony is negational" (1973: 34; italics in the original). In other

13 E.g., Northrop Frye's famous book Anatomy of Criticism (1957) plays a prominent role in White's work in Metahistory.

14 White later denied that the book has any general theoretical or methodological valueyears after writing it, he claimed its contribution was strictly analytical. White's opinion of his own work notwithstanding, however, there is no reason why one should not build upon the fundamental ideas that undergird his study. His work certainly can and has informed historical theory, as I comment below. In any case, he does not seem to mind that many historians "have found something useful in [his] book." See his insightful comments in Domańska et al. 1994: esp. 93-94. 
words, while the first three tropes maintain some connection between a real past and any present representations of it, Irony undoes this connection. So Ranke, for example, thought about the past primarily Metaphorically (White 1973: 167) and Nietzsche was, obviously, Ironic, even as he attempted to transcend the trope (White 1973: 376). On these kinds of points especially, scholars have rightly criticized White for being too schematic and for not sufficiently connecting his actual analyses of nineteenth-century works with his theory of historical tropes. ${ }^{15}$ White's discussion of tropes and historiography, nevertheless, sparked intense discussion among historians and other members of the academy in relation to historical preconceptions and representations of the past.

Rooted as it was in analyses of specific nineteenth-century historians and thinkers, Metahistory's applicability as containing a general theory of historical thought was limited (as White has repeatedly emphasized over the years), but it raised important questions about the linguistic and literary nature of historical work that sent shockwaves through the discipline and though the humanities more generally. Indeed, although White himself eventually abandoned the concept of tropes as a theoretical framework, ${ }^{16}$ he continued to push the issue of historical discourse and its fundamentally figurative and literary qualities. In seminal essays such as "The Historical Text as Literary Artifact" (1978: 81-100), "The Fictions of Factual Representation" (1978:121-34), and "The Value of Narrativity in the Representation of Reality" (1987:1-25), White tested the boundaries between "history" and "literature," between representations of "fact" and of "fiction," between what is considered "real" and "imagined," and between other discursive concepts generally thought to be somehow opposed to one another. He has repeatedly emphasized that the modes of discourse

15 E.g., Ewa Domańska (1998b: 175) reads Metahistory's introductory chapter ("The Poetics of History," pp. 1-42), which has caused abundant consternation among historians, as an entirely separate work from the rest of the book; and John Nelson (1975: 82-83) states that, instead of showing that the linguistic style of a specific work is steeped in, say, Irony, White simply argues that the over-arching "attitude" of the work is ironic. Cf. Keith Windschuttle (cited in Green and Troup 1999: 207-208), who takes issue with White for arguing that "relatively minor stylistic devices" constitute "deep foundations that determine the whole structure." White, it seems, took some of these criticisms to heart. In the years following Metahistory's publication he produced a number of essays that sought to refine the theory (e.g., 1978: 1-25), though ultimately he distanced himself from it in the 1980 and later, as I comment below.

16 In his widely read collection of essays The Content of the Form (1987), for instance, he mentions the word "tropes" only a single time, on p. 47. Cf. Domańska et al. 1994: 95. 
found in academic historiography are commonly found in other forms of literature, and that this should inform how we think about and with history. ${ }^{17}$

How a historical work narrativizes its content-i.e., how it constructs a certain kind of story out of historical data-is not unlike how non-historical works narrativize their content. Histories are tragic, epic, comedic, romantic, and so on; they are thrilling, banal, political, artistic and so forth, in the same ways that short stories and novels and even Hollywood films are all of these things. The narrativity of a factual account of Napoleon's France, for instance, however constructed, could be precisely the same as the narrativity of a fictional novel focused on the same era. Likewise, a factual narrative construction of an ancient Near Eastern king's military exploits could mirror an entirely fictional narrative construction of that same king and his accomplishments. In terms of narrative, there is little, if any, difference. In drawing parallels between fact and fiction, however, White fairly consistently maintains the position that, although there are literary and narratival similarities between histories and novels for example, the historian and the novelist generally work with different sorts of data or-perhaps more accurate — data that is constituted in different ways and in different professional contexts (e.g., White 1987: 27; 2014: xiii). It is not facts or reality as such that White wants to question vis-à-vis history, but the modes of discourse through which past realities are represented as history. White never questioned the existence of historical facts or the reality of the past; he critiqued, strictly speaking, the narrative representations of those facts and that reality.

White's work, nevertheless, grated at the sensibilities of many historians. Unsurprisingly, those operating within mainly empiricist frames found White's work untenable, but a number of historians with sympathies for the linguistic turn and emerging theory found White's ideas difficult to accept, too. If history and fantasy, for example, are formed out of the same sorts of narrative and literary discourses, how does one distinguish between the factual or real past and the fictional or fantastical? In Paul Ricoeur's words, how do we specify "the referential moment that distinguishes history from fiction" (2004: 253)? White's insistence on the existence of past realities is one thing, but actually discerning those realities vis-à-vis historical discourse is another. The parallels between factual and fictional representations can make it difficult to determine the factuality of any given narrative account once it is constructed. ${ }^{18}$

17 For a thorough and excellent account of White's career and his scholarly contributions during it, see Paul 2011.

18 A main flashpoint of debate between White and his detractors on this issue was the Holocaust (see, e.g., White 1987: 75-76; Green and Troup 1999: 209-10; Crane 2002: 331-33; 
This is especially true if there is no data to corroborate the facts, beyond the narrative itself, as is often the case with peoples, places, and events described in the texts of the Hebrew Bible.

Today, a number of historians working in a variety of fields would agree with White's basic points about the narrativity of historical discourse: i.e., that historiography has much in common with other literary forms; and that these forms, historiography included, communicate certain (pre)conceptions of the world and reality in it via their modes of emplotment, argumentation, and ideology (cf. Partner 2009: 84-85). But among historians there remains a general discomfort with White. Some would argue that, if his ideas are taken up fully, they can lead to an absolute relativism that hamstrings one's attempts to distinguish between history and fiction, between the real and fantastic, truths and lies, and so on. For these historians, White was "a gadfly, an unwelcome critic of a hallowed discipline with ancient roots," as Robert Doran has described the situation, and "White's rapprochement between literary or fictional storytelling and the historical or biographical account amounted to an indictment of history as a factual discipline" (in White 2010: xv). But again, White does not deny the existence or reality of facts per se, what he calls "singular existential statements" (White 1987: 45). Statements like "Napoleon was a French military leader" or "Sennacherib was king of Assyria" are verifiable and true, amply documented and beyond question. What concerns White is the selection and

Ricoeur 2004: 254-61; Nichanian 2009: 59-90). In 1991, historian Saul Friedlander convened a conference in Los Angeles, the sole task of which, according to Marc Nichanian (2009: 6o), was to take White to task on the issue of historical truth, with Nazism and the Shoah as a reference point (cf. Friedlander 1992: 2). In addition to Friedlander and White himself, a group of internationally renowned scholars gathered to discuss the event and its history, its representation and interpretation, and the problems inherent to historicizing genocide. As many scholars have discussed at length, the fact of genocide is an aporia: it has happened, does happen, and yet its horrors are irreducible to any definitive representation. Nichanian (2009), for example, provocatively states that genocide is "the very destruction of the fact, of the notion of fact, of the factuality of fact" (1) in order to introduce his penetrating reflection upon the Armenian genocide of 1915, its history and testaments to its reality. In writing any history of the horrors of such events and their perpetrators, whose very goal is to annihilate the fact of a people's existence, one confronts the "specter of revisionism" at every turn (Nichanian 2009: 62). The issue is a stark reminder of hermeneutical circularity in history. How do politics inform interpretation of an event, and vice versa, and how does this political and interpretive interrelationship contribute to the confirmation or constitution of any event's reality in the past vis-àvis the present? Carlo Ginzburg (1992), a participant in the 1991 conference and perhaps White's sharpest detractor there, verged on the claim that White perpetuated fascism. And White, in response, called Ginzburg naïve and even hypocritical in his (Ginzburg's) dealings with the problem of representation in historical discourse (in Domańska 1998a: 16). Today, very few historians, if any, would accuse White of fascism (cf. Paul 2011: 119-24). 
ordering of facts into narrative forms whereby they are read and interpreted as historical representations. Thus, he once wrote:

Every mimetic text can be shown to have left something out of the description of its object or to have put something into it that is inessential to what some reader, with more or less authority, will regard as an adequate description. On analysis, every mimesis can be shown to be distorted and can serve, therefore, as an occasion for another description of the same phenomenon, one claiming to be more realistic, more "faithful to the facts."

WHITE 1978: 3 ; italics in the original

So, it is interpretations, and not facts, that are relativistic in White's thinking. "By separating fact from interpretation," Doran comments, "Whsite thereby steers a middle course between objectivist historicism (there are no interpretations, only facts) and Nietzschean perspectivism (there are no facts, only interpretations)" (in White 2010: xxvii). It is his commitment to the middle, however, that sometimes proves to be problematic; hence, the challenge of representing and interpreting an event like genocide, which as a phenomenon is defined by the fact of erasure, and the horrific realities of which are irreducible to any single perspective or truth. ${ }^{19}$

In any case, most historians have taken White's arguments in stride, nodding consent to his general insights about historiography but relying nonetheless on disciplinary consensus with regard to historical method and criticism, the identification and verification of relevant facts in historical research, and so forth. As Ricoeur (2004) points out, White seldom ventures into detailed discussions of what Ricoeur calls "the documentary moment and its generating matrix of presumed truth - that is, the testimony of those who declare their having been there where things happened" $(254) \cdot{ }^{20}$ And historians today

19 In his latest book, White once again comments on the challenge of representing genocide, in an essay entitled "Truth and Circumstance: What (if Anything) Can Properly Be Said about the Holocaust?" (2014: 25-39), especially in relation to artistic or aestheticized or dramatic representations, such as well known films like Schindler's List (1993) or La vita è bella (Life is Beautiful; 1997).

20 This is perhaps because, as I have emphasized above, White took "the documentary moment” for granted, never really denying historians' abilities to establish certain facts. I should note here, too, that White worked as a historian throughout much of his career, despite claims to the contrary by other historians who wish not to recognize him as a fellow practitioner of the discipline (Vann 2009). (A related note: White's role in scholarship is an ongoing point of debate. In the end, should he be recognized as a historian, cultural theorist, literary critic, philosopher, something else? For instance, the American 
remain reasonably confident in that documentary moment in their work. Recognizing the complex epistemological issues at stake here, suffice it to say, as Ricoeur (2004) does, that in modern historiography there is an "implicit contract between the writer and the reader" based upon the historian's commitment to cast a critical eye toward evidence and to present accounts of it that are "honest and truthful," and that "more or less approach what one day was 'real'" (261-62). Basing their work first and foremost on critical investigation of evidence that indicates past realities, historians - as opposed to, say, novelists - intend to craft representations that "stand for" the real past, despite the affinities between factual and fictional representational discourses. ${ }^{21}$

Historians who work with the Hebrew Bible as a source intend to do the same, of course, to craft reliable representations of ancient Israel and Judah. But historians working with the Bible lack essential information about the ancient "documentary moments" of the Bible itself. Dealing with a thoroughly narrativized source to answer historical questions about these ancient contexts, biblical scholars often lack the data necessary to make confident historical judgments, to craft their own historical narratives of ancient realities. In the Bible's particular case, White's critiques of historiography and narrative representation are incisive, because they force those of us who work in biblical studies to reflect upon the narrativity of our primary source, and to find new theoretical tools for unpacking and understanding the import of such narrativity for our historical reconstructions.

For most historians, then, the fruits of White's labor are the questions he raised rather than any specific conclusions he reached (cf. Allan Megill, in Domańska 1998a: 6; also Rigney 2013: 186). Today, historiographical work

Academy of Arts and Sciences, in 1991, inducted him into its "Literary Criticism (including Philology)" section [see Bulletin of the American Academy of Arts \& Sciences, Fall 2016, p. 162]. And Paul Roth [2013] has argued that White should be read primarily as a philosopher. White's career has been truly interdisciplinary, but his work-whether literary-critical, theoretical, philosophical, or whatever - has always had ties to history and historical research.)

21 That said, there is an irony, perhaps paradox, in the fact that history's "standing for" the real past-i.e., the move from documentation to representation-relies upon narrative modes of discourse that history shares with non-historical literature, thus forming history in such a way that is alien to the facts themselves. In its standing for the past, via discursive representation, history depicts reality and yet distorts it. On this point, argues Ricoeur at least, historians are forced to fall back upon their trust in critical investigation, in their ability to demonstrate that something has been despite its being no longer. "[W]e have nothing better than our memory to assure ourselves of the reality of our memories - we have nothing better than testimony and criticism of testimony to accredit the historian's representation of the past" (Ricoeur 2004: 278). 
cannot take for granted the modes of discourse it employs, nor can it carry on without acknowledging certain preconceptions about, and the inherent challenges to, representing past realities. White's exhortations for scholars to acknowledge and deal with narrativity in history has led to a healthy selfreflexivity and even self-criticism, for those with ears to hear (Halttunen 1999). Scholars have recognized the "value of narrativity," to use one of White's own expressions, and in doing so they have also recognized the value of probing and challenging narrative coherence and correspondence with the past, in order to make room for multiple perspectives and better reasoned interpretations of past realities (Rigney 2013: 193-94). The insights and challenges of narrative, it seems, are here to stay (cf. Partner 2009: 86-87). Narrative shapes who we think we are as individual persons, and as persons interrelated to other individuals, within society. To cite Ricoeur again, "People have always told stories" (in Dowling 2011: 109), and telling stories contributes to the articulation of self and social understanding. This articulation, in turn, has been a key impetus for the writing of history, and for thinking about the writing of history, in our contemporary historical context.

\section{Bringing Together Culture and Narrative in History: Social} Remembering

Thanks in large part to Hayden White, Paul Ricoeur, and their interlocutors, it has become clear and unavoidable that the writing of history is wrapped up in the narrativity of social life. Moreover, as White's major arguments became prevalent points of discussion in the academy, it became clear that the narrative strategies individuals and groups use to bring the past into the presenti.e., the means by which people remember the past-were vital talking points for historians. Thinking about narrative, then, especially the hows and whys of its construction in the processes of historical inquiry, as in the work of White and his colleagues, pushed historians to be more self-reflexive, as I outlined above, but it also correlated with increased interest in memory and remembering in history. In short, over the years, narrative and memory have established a good working relationship, especially in the field of cultural history. Social memory, as a social narrativization of the past, has proved to be a productive concept for thinking about how meanings have been and are constructed in certain historical contexts. For Hebrew Bible studies, the concept can helpfully bring together cultural-historical and narratival interests. ${ }^{22}$

First of all, memory is a cognitive function of the individual mind. It consists of the many ways by which the human mind stores and recalls information, 
consciously and unconsciously (Boyer 2009; Landy 2012: 331-36). Humanities scholars, in general, have mostly been interested in what cognitive psychologists call "episodic" memory, that is, how the human mind stores and recalls information about specific persons, places, events, and so on. ${ }^{23}$ According to recent research, the mind continuously (re)organizes episodic memories into narrative(s), creating an autobiography that helps construct a sense of self and a personal identity. From around the age of five years, the constantly evolving autobiographical sense of self impacts the ways in which episodic memories are stored in the mind, and vice versa: the changing sense of self continuously alters the ways through which one constructs, prioritizes, and narrativizes episodic memories (Boyer 2009: 5-9). Thus, the remembering (and forgetting) of life's phenomena, the ongoing construction of personal narratives out of those phenomena, and one's evolving sense of self all contribute to a cognitive feedback loop that continues throughout one's life, constantly shaping and reshaping one's memories and personal identity - this is an important point to which I return below.

These individual mnemonic processes, however, do not occur in isolation. Humans are social beings; we live in society, constantly interacting with other individuals. Thus, for at least the last century, scholars have explored the ways through which society shapes and reshapes individual memories, how society impacts memory, and vice versa (Olick and Robbins 1998; Misztal 2003; Williams 2011). Generally speaking, scholars have referred to these processes as "social" or "collective" memory. Simply put, social or collective memory is "the interplay of present and past in socio-cultural contexts" (Erll 2010: 2); or, in the words of Maurice Halbwachs, it is "a reconstruction of the past [that] adapts the image of historical facts to the beliefs and spiritual needs of the present" (in Schwartz 2000: 5$)^{24}$

23 Although cognitivists often distinguish between different types or categories of memory (e.g., semantic, episodic, etc.), it is important to note that each of the various types are, in some way, dependent upon one another. Semantic memory, which is how our minds process a present sensory experience based on prior sensory experiences, helps contribute to episodic memory and provides the cognitive framework that makes it possible (Boyer 2009: 9).

24 Halbwachs saw memory and history as antonyms (cf. Assmann 2011 [German original, 1992]: 28-31). Today, a reader might question the difference between Halbwachs's definition of collective memory and postmodern conceptualizations of history. In the wake of the linguistic turn, the concept of memory, in some works, has merged with and even become a synonym for the concepts of history and historiography, which flips Halbwachs antonymic position on its head. Thus, Klein (2000: 127-50) criticizes this turn to memory studies in the discipline of history, especially in cases in which the concept is under theorized. Klein's criticisms of the use of "memory" are well-taken. However, for at least the 
One should note, however, that there is no such "thing" as social or collective memory (Olick and Robbins 1998: 112; Wertsch 2009a: 118-24). There is no "mystical group mind"; there are, instead, "sets of mnemonic practices in various social sites," as Jeffrey Olick and Joyce Robbins (1998: 112) put it. An individual actually has distinct memories; a society does not. This perhaps goes without saying, but it is worth mentioning in order to avoid the pitfall of thinking about a group's social memory as a monolithic entity that one can discover or reveal by studying said group. In theorizing about social memory, one may transfer what we know about the processes of individual cognition to the level of society, but only metaphorically and heuristically. Astrid Erll (2010) writes, "Societies do not remember literally; but much of what is done to reconstruct a shared past bears some resemblance to the processes of individual memory, such as the selectivity and perspectivity inherent in the creation of versions of the past according to present knowledge and needs" (5). Therefore, in line with Olick (2007: 10), it is perhaps more productive to speak of mnemonic practices

last two decades, there has been a conscious and critical effort to reflect on and refine the theoretical and methodological import of social memory as a concept in the study of history. See, e.g., Confino 1997: 1386-1403; Olick and Robbins 1998: 110-12; and Schwartz 2000: 9-12. Memory and history can be productive conversation partners, if brought together with due attention to their interrelationship. It is important not to collapse the concepts of history and memory into one and the same, but neither should one see them as completely distinct and separate. Consider the thoughts of Hayden White:

"It is memory, after all, that compels us to confront the enigma of how what is past can perdure into the present and, no matter how we might wish it, that refuses to go away on command but remains present to consciousness, even getting in the way of perception and pressing for attention however distracted we may be by current affairs. Memory, or a sense of absent presence, is the basis of a particularly historical consciousness, even if history has conventionally been presented as a corrective to memory and a more reliable approach to the study of the past than 'memorization.' ... History seeks to discipline memory by setting up standards regarding what should be remembered and in what manner and what form. Thus, history is memory cultivated in the interest of producing a 'collective' past on the basis of which a collective identity can be forged. In many respects, therefore, historical knowledge is disciplined memory, based on some extra-historical criterion of what can be legitimately remembered and, indeed, what ought to be remembered and what ought to be forgotten by members of the community." (2010:320)

Cf. Barstad 2010. See also the recent and nuanced study of Daniel Pioske (2015b), which draws on Ricoeur 2004 and seeks to develop a hermeneutic that situates "referential claims of a particular cultural memory within a broader context of ancient referents in order to determine if the past represented through it is commensurate with these other material and textual traces" (306). Thus, situating the claims of a society's shared memories within a larger complex of interrelated historical data, and analyzing the memories vis-à-vis that data, can help us (a) develop a sense of the society's own epistemology and (b) refine our historical reconstructions of that society's past. Pace Jan Assmann (2011 [1992]), who writes, "[M]emory has nothing to do with the study of history" (6o). 
and social remembering, whenever possible, to avoid reifying social or collective memory as an entity.

It is also worth noting that there is no practical way for the historian, especially one working on antiquity, to separate individual and social processes of remembering. (Cognitive psychologists and neuroscientists are able, to a certain extent, to separate these processes better, but that is because they are working with living individuals in the present day.) Just as one cannot reify social memory as a monolithic entity, so too one cannot effectively separate individual memories from their sociocultural milieu. Individuals remember independently, of course, but everyone's memories are shaped and informed by cultural preferences, common narratives, mutual experiences, and so on, which are known and shared within social contexts. Any historical investigation into an individual memory from the past necessarily says something about that individual memory's place within a larger complex of social remembering. The individual remembers, a cognitive function that is socially shaped; the society shares certain elements of a past that shapes individual remembering; and the individual, as part of the society, acknowledges and legitimizes these shared elements of a past by integrating them into his or her memory-the processes are contingent upon one another.

With regard to social memory, then, what the historian can do is investigate those shared elements in a particular social setting, the lieux de mémoire ("sites of memory," as the phrase is often translated ${ }^{25}$ ) of a society, in order to gain some insight into how social remembering happens (Nora 1989; Ricoeur 2004: 401-11; Den Boer 2010). One can explore the lieux on which mnemonic practices are focused. Sites of memory help bridge the gap between individual and collective mnemonic processes. These sites are anything that carries a "symbolic aura," whether material or non-material in nature, actual or abstract, which is widely circulated and/or experienced in a given society (Nora 1989: 13-14). These can be, for example, places (the Coliseum in Rome), events (September 11 in the United States), persons (Napoleon in France), works of literature (the Mahabharata in India), or even a concept or idea (Darwinian evolution in the scientific community), among many other things-it is important not to

25 Nora's initial use of the term lieux, in the 1970s and 8os, was rather limited in scope: it referred especially to ideologically loaded, nationalistic symbols (e.g., propagandistic monuments, etc.) that, he argued, could not be value neutral (Den Boer 2010: 21). As the term has spread in the academic world, its meaning has become more abstract. This is apparent in Nora's own work. For example, in an essay for a German publication in 2001, Nora translates his own term variously, using Herde (centers), Knoten (knots), Kreuzungen (crossings), and Bojen (buoys) for lieux, thus suggesting the multiple functions of a simple "site" of social memory (Den Boer 2010: 22-23). 
limit "sites" to physical (or even real) places and things. Of course one could classify each of these examples in another situational category (in many ways Napoleon is both a person and an event). And a site may have different functions in different sociocultural contexts, different time frames, and so forth. So, for example, the figure of Napoleon means something different in France than he does in Russia, and he meant something different to inhabitants of Europe in the eighteenth and nineteenth centuries than he does to Europeans today. This is also true for various subgroups within larger sociocultural milieux. September 11 obviously has different meanings for the countless identifiable geographical, political, religious (the possible adjectives go on) groups in North America and throughout today's globalized world. The most salient sites of social memory are often overdetermined (Said 2000). The social matrix that informs remembering represents a huge network of cultural signification, and the various sites of memory are signified in different ways.

Historians consider social memory and remembering, then, within the "symbolic universe available to the society," within the sociocultural matrix that informs and guides group identity and experience (Confino 1997: 1391). One might suggest that this symbolic understanding of social memory is akin to Geertzian cultural anthropology, which I discussed above. Without a doubt, Geertz's work has had an impact on social memory studies (Erll 2010:4). Memory per se was not a socially systemic conception to which Geertz turned his thoughts (though he was certainly concerned with questions of the mind), but one can think of the complex of social remembering as a Geertzian cultural system.

Indeed, the historical sociologist Barry Schwartz $(2000 ; 2008)$ has done just that. In his important work on the figure of Abraham Lincoln in American social memory, Schwartz convincingly shows how sites of memory function systemically in the negotiation of past and present. In particular, he shows how various representations of Lincoln (including written and visual) helped reflect, program, and frame discourses about leadership, democracy, and national unity in twentieth-century America. For instance, in 1963, Lincoln became the go-to symbol for thinking about the assassination of John F. Kennedy, helping frame the unexpected tragedy of Kennedy's death. And as a corollary, Lincoln's memory - the grandeur of which had diminished somewhat in the years after World War II - received new life via the figure of Kennedy (2008: 221-28). In this way, social remembering is dualistic. "The past," writes Schwartz,

is matched to the present as a model of society and a model for society. As a model of society, collective memory reflects past events in terms of the needs, interests, fears, and aspirations of the present. As a model for 
society, collective memory performs two functions: it embodies a template that organizes and animates behavior and a frame within which people locate and find meaning for their present experience. Collective memory affects social reality by reflecting, shaping, and framing it. ${ }^{26}$

SCHWARTZ 2000: 18; italics in the original

Thus, when one views a particular image through the frame of memory, one envisages that image within its cultural background, within a myriad of symbolic, cultural associations that help shape the frame itself. That said, it is important to note that this dualistic nature of social remembering is distinguishable only from an analytic perspective. In mnemonic practice, both aspects are present simultaneously. Schwartz explains,

Memories must express current problems before they can program ways to deal with them, for we cannot be oriented by a past in which we fail to see ourselves.... On the other hand, the programming and framing functions of memory are what make its reflexive function significant, for we have no reason to look for ourselves in a past that does not already orient our lives.

SCHWARTZ 2000: 18-19

So, in 1963, one must have understood Kennedy as somehow evoking Lincoln before Lincoln could become a frame for understanding Kennedy; yet for Kennedy to evoke Lincoln, one must have already had Lincoln in mind (consciously or unconsciously) as a past figure that could orient thinking about the present. In the words of Jeffrey Olick (2007), “[M]nemonic practices express neither the past nor the present but the changing interactions between past and present: Past meanings are malleable to varying degrees and present circumstances exploit these potentials more or less" $\left(55^{-} 5^{6}\right)$. The past and the present are in constant negotiation, modeling each other in a feedback loop that enables sociocultural identification and orientation.

Lincoln is a fantastic example of memory as a cultural system because, as a widespread symbolic site of memory whose meaning is contingent upon sociocultural and temporal contexts, he became a multivocal and polyvalent figure that framed thinking about many different persons and events in American society, thus supporting sometimes contradictory ideals. Prior to the Great Depression in the United States, for example, Lincoln was symbolized both as an everyman and as an unmatched (super)hero, simultaneously embodying

26 Here Schwartz draws directly on Geertz 1973: 93-94. 
egalitarianism and a strongly defined political hierarchy, and revealing divisions in thought about what America is and what its leadership should be (Schwartz 2000: 256-92). This discourse continues even today. ${ }^{27}$ What one finds in Schwartz's work is a number of narratives about Lincoln, each of which contributed unique statements to mnemonic discourse-Lincoln the Emancipator, Lincoln the Self-Made Man, Lincoln the Savior of the Union, etc. - and each of which provided a model of and for American society in particular twentieth-century cultural settings.

Understanding social remembering, then, requires an understanding of the continuities and discontinuities in various strands of narrative thought shared in a society, and how these act and interact as sociocultural models. Memory, therefore, in my usage here, is a sociocultural system that helps construe communally shared narratives about the past. These narratives interact with one another, reinforcing knowledge of particular episodes and socially shared ideas, and forgetting (or: bracketing) others. They are constantly (re)shaping the past and its meaning and import for the present and future. Thus, like an individual who constantly forges personal identity via the (re)shaping of one's autobiographical narrative, societies continually (re)construct group identity via shared narratives about their past, narratives that often complement each other but sometimes paradoxically contradict one another. Further, as Olick (2007: 27-30) emphasizes, a number of mnemonic practices consciously and unconsciously facilitate the processes of social remembering and the (re)shaping of shared narratives and group identity. These include ritual observances, visiting and viewing commemorative monuments (and their construction in the first place), pilgrimages to ideologically loaded locales, and the production and dissemination of authoritative texts and their ideas, among other things. ${ }^{28}$

27 E.g., Steven Spielberg's recent Oscar-winning film, Lincoln (2012). The film stirred up much discussion about history, politics, and popular film. On November 15, 2012, the Obama administration screened the film at the White House for a select group of Congresspersons (all Democrats-apparently Republicans were invited, but none attended), bringing the film directly into the contemporary political arena.

28 This approach, it is worth noting, is quite different from Jan Assmann's influential work on memory (e.g., 2011 [German original, 1992]; 1997). His work has spawned great academic interest in what he calls "mnemohistory," investigating "the history of cultural memory" - that is, how a particular subject from the past is treated discursively over long periods of time, "over generations and centuries, even millennia, depending on institutionalizations of permanence such as writing, canonization, educational and clerical institutions, and so forth" (1997: 15-16). Assmann's work, then, is ultimately an exploration of transmission of the past. Moreover, he understands "cultural memory" as transmissive in the first place. It is "the handing down of meaning" via significant acts of communication (2011: 6). So, cultural memory is transmission of the past on a micro-scale, while 
If the shaping of individual as well as group identity is intricately linked to the shaping of narratives about the self or group, then narrative constructionwhere the stories start and end, the ordering of chronology, what is emphasized and deemphasized (or left out), the syllogistic reasoning of causation in the plots, and the ideological preferences in the narratives - reveals at least one essential element in the workings of identity construction. Therefore, as one might expect, narrative criticism has been a helpful tool in studies of social remembering (Wertsch 2009a: 120, 128-32; cf. Fentress and Wickham 1992: 87-88). Indeed, Schwartz (1998) likens the modeling aspect of social memory, the framing of the present with past images, to the emplotment of a historical narrative: within a mnemonic system, sites of memory that function as frames for the present (and future) define "the meaning of problematic events by depicting them as episodes in a narrative that precedes and transcends them" (8). Of course, this is also the case for non-problematic events, persons, and so on. It is the narrativity of remembering, in any case, that contributes to the potential for the production of meaning in social memory.

Here we may return to the work of Hayden White to help us unpack the interplay between historical discourse and narrative within the processes of social remembering. Embedded in any history's narrativity, White argues, is a

mnemohistory is the macro. Now, I should state that Assmann does acknowledge the importance of (essentially) synchronic, socio-mnemonic shaping of individual and group identity, processes like those I have outlined above. He calls this "communicative memory," and distinguishes it from cultural memory because it lacks the transmissive aspect (2011: 6-7, 34-44). However, I find this distinction overly schematic. The lines between "the everyday and the festive, the profane and the sacred, the ephemeral and the lasting, the particular and the general" (2011: 43), are not so easily drawn. To a certain extent, his schema are insightful from an analytic perspective, but the distinctions break down in real time. Indeed, everyday experiences shape the experience of ritual festivals, and vice versa. It is difficult to untangle them in the complex social processes of signification. The same is true for the interrelationship between the mythic (which Assmann sees as part of "cultural" memory) and the recent or living (part of his "communicative" memory). For example, one thinks of Martin Luther King Jr. giving his famous "I Have a Dream" speech before the Lincoln Memorial, a speech that also directly alluded to the Gettysburg Address and the Emancipation Proclamation; or King's stepping into the role of Moses in his final public appearance, via the speech "I've Been to the Mountaintop." Is King, a figure within living memory in the United States, any less mythic or foundational in American culture than Lincoln or Moses? And are any of these figures somehow excluded from shaping our everyday experiences (our "biographical" memory, in Assmann's term) because they are not properly "communicative" memories? In any case, this is not to say that Assmann's approach is unhelpful for historical study; it can be a rather useful schema for thinking about the transmission and reception of certain ideas in sociocultural contexts. For understanding the function of memory in any precise social and historical context, however, Assmann's approach is perhaps less useful. 
discursive statement about historical consciousness, about the meaning and import of the past for the present as represented in that history. He states, "When the reader recognizes the story being told in a historical narrative as a specific kind of story - for example, as an epic, romance, tragedy, comedy, or farce- - he can be said to have comprehended the meaning produced by the discourse. This comprehension is nothing other than the recognition of the form of the narrative" (1987:43; cf. Wilson 2013: 314-15). The form (narrative) therefore has content (narrativity), which actualizes the history itself. To get at this discourse, as I described above, White emphasizes the means by which the history is told: the structure of the plot, the modes of argumentation employed, and the worldviews embedded in the history. Receiving and thinking on a particular history (or any historicizing account), therefore, contributes a corresponding discursive statement to one's memory, and is instrumental in the ongoing (re)construction of identity, one's sense of self and other in a specific context. And of course all of this feeds back into the production of historical discourse in a social context.

It is narrative, and specifically the emplotment of narrative-i.e., the narrativity of historical thought-that enables human societies to make sense of their places within the progression of time (cf. Ricoeur 1984-1988; 2004). Jan Assmann (2010) puts it this way, "Memory enables us to orient ourselves in time and to form out of the stuff of time a 'diachronic identity.' Political myths [i.e., traditional narratives] are about forming a collective or political identity, and they achieve this by giving time the form of a narrative structure and charging this structure with values, emotions, and ideals" (14). This is true for any society, ancient or modern, that has a historical consciousness, as Israel and Judah no doubt did. Looking back on the past, one recognizes a narrative structure that leads to the telos of the present (or future), and one reads or recalls this narrative both "backward" (one has some idea where it is headed) and "forward" (one has to piece together the "whys" of the narrative as it unfolds); narrative temporality thus has two sides (Ricoeur 1984-1988: 1.45-77; Dowling 2011: 10; cf. Newsom 2006: 218-19). Put differently, one has a preconceived idea of what type of narrative one's past is (tragic, comic, etc.) and thus of its trajectory over time, yet one also has to figure out how the narrative went from one episode to another through time (causality), giving some sense of meaning to the process.

According to Ricoeur, anagnorisis (an Aristotelian concept, the aha! moment in a narrative) occurs when these two perspectives - trajectory and causality - converge, when one's narrative expectation is realized in the unfolding and interconnected events of the plot. For a narrative to be successful, this moment must be persuasive and provide a certain amount of catharsis for 
the reader (Ricoeur 1984-1988: 1.49-50). "Men in the middest," writes Frank Kermode (2003), "make considerable imaginative investments in coherent patterns which, by the provision of an end, can never be permanently falsified" (17; italics in the original). The (re)shaping of social memory and identity occurs as groups make these realizations in their shared narratives (cf. Ricoeur 2004: 80-86): Where and when did we come from? How did we get here now (and how will we get to our future)? When and why did that and this happen to us, for better or worse? Of course many of the minute details of a narrative, the finer points of emplotment, may be chaotic and inexplicable, effecting some amount of fluidity in one's answers to such questions.

Following this line of thinking, I would submit that meaning within social memory is first and foremost a function of narrative emplotment, as it is with historical discourse. Other narrative elements, such as characterization of important past persons, certainly contribute to our socially shared interpretations of the past, but these elements are at least partially dependent upon emplotment (Jobling 1998: 6-7). This approach to narrative criticism (i.e., reducing narrative elements such as characterization to functions of plot) is common but not without its critics (Baker 2011: 21-22). While it is true that plot and characterization are interdependent, in the case of historical discourse and social remembering I argue that perception of a past person's character happens secondarily to the perception of telos in the person's story. In the processes of social remembering, what one contributes to the ongoing narrative of society is more important than the perception of an individual's overall "goodness" or "badness." In the end, socially shared narratives and their emplotments tend to emphasize certain contributions and outcomes in a person's life; they encourage readers to remember certain details, while forgetting, bracketing, and deemphasizing others.

A couple of examples from the Hebrew Bible will be helpful here, as we work toward thinking about these issues in relation to biblical studies. First, the perception of Samson's character, for instance, largely depends upon whether or not a reader thinks his life is a success, whether or not his narrative contributes something positive to Israel's overarching story, and in what ways it does so or does not (see Judges 13-16; Eynikel and Nicklas 2014). As a selfish brute with a penchant for foreign women, he certainly is not a "good" Israelite in accordance with Torah. Nevertheless, in 1 Samuel, Samuel himself recalls Samson as a successful deliverer of the people (1 Sam 12:11; cf. LXX, Peshitta, Targums), and the book of Hebrews in the New Testament commends Samson, along with Gideon, Barak, Jephthah, David, and Samuel (all less than "good" characters in one way or another), as men "who through faith conquered kingdoms, administered justice, obtained promises, shut the mouths of lions, 
quenched raging fire, escaped the edge of the sword, won strength out of weakness, became mighty in war, put foreign armies to flight" (Heb 11:33-34, NRSV). Consider Solomon, too. According to 1 Kings 11-12, his life ends tragically and his exogamy and idolatry lead directly to the division of Israel. Solomon, however, was also conceived as a model king, as the one who ultimately fulfilled the promise to David by building Yahweh's temple (cf. 1 Chr 28:5-6). In Chronicles the exogamy and idolatry are forgotten, and Solomon stands on par with David as a benchmark for Israelite and Judahite kingship and for Yahwistic devotion (cf. 2 Chr 30:26; 33:7). ${ }^{29}$

Present-day discourse provides another good example of the primary importance of emplotment in social remembering. We in North America (and abroad) are currently in the ongoing process of remembering the technological innovator Steve Jobs, cofounder of Apple Inc., who died in 2011. It is widely acknowledged that Jobs was a very difficult person. It seems he was not a very likeable character. But this perception of Jobs's personal character does not seem to negatively affect the public's generally positive view of him as the leading mind behind Apple and its products. In short, because people think Apple turned out great, people think Jobs is great. Journalist Megan Garber puts it extremely well:

We tend to recognize people of this caliber, through history's fuzzy filter, not so much for who they were but for what they did. And that pragmatic approach to progress tends to reduce greatness, in turn, to binary questions of person and product. Newton gave us gravity and Einstein gave us relativity and Madison gave us representative democracy, and all the other details of their lives and their characters tend to erode, in the public mind, with the wash of time. Were the Great People of history kind? Were they funny? Were they jerks? It doesn't much matter in retrospect, because they - their work - made the world better. The other stuff, the human stuff, is inconsequential. ${ }^{30}$

GARBER 2013: n.p.

29 Solomon is, obviously, a complicated case. For instance, Sir 49:4 does not list Solomon among the great kings of Judah. Nonetheless, his narrative in Chronicles nicely demonstrates my point here. On the Davidic promise(s), and its relation to issues of dynasty, temple, and Torah, consult Wilson 2017: 131-81 and passim.

30 Garber's essay is a critique of the biographical film Jobs (2013), which depicts Jobs heroically. A more recent biopic, Steve Jobs (2015), presents the iconic figure in more negative light. On the issue of character and reputation in social remembering, see also Olick and Robbins 1998: 130-33. 
Of course, retrospection might change as time wears on; if for some reason down the road Apple's technologies are judged to have had a negative effect on society, then Jobs's character will be judged accordingly (a kind of confirmation bias). Within the Hebrew Bible's narratives, if Solomon were to turn to foreign women and idolatry without building the temple, perhaps he, and not Jeroboam, would be judged as the great failure and negative ideal. Another example: if Josiah were to die mysteriously at the hands of Neco before finding the law book and reforming the cultus, perhaps he would have gone down as another Manasseh. At least in these types of discourse, the contribution of one's life to society's ongoing history, to the trajectory of its plot, ultimately trumps one's characterization.

Social remembering, then, functions primarily within narrative frameworks of thought, which have structured plots, inherent understandings of causality, and preconceived ideas about social praxis (i.e., ideologies). These narratives link together different sites of memory within discourses (e.g., persons, places, events), shaping larger sociomental matrices, and contributing to an overarching mnemonic system, which serves as a model of and a model for society - a Geertzian conceptualization of culture. As part of an ongoing, discursive feedback loop, social memory (re)shapes understandings of the narratives and, in turn, group identity. Such (re)shaping happens via conscious and unconscious contestation (what to remember? what to forget?), and via the intrinsic malleability of socially shared stories about the past, present, and future (Olick and Robbins 1998: 122-30). Obviously, this complex cultural system and these sorts of questions relate directly to history, both as a mode of discourse that addresses such questions and as an academic discipline that produces the discourse itself. Memory and history thus function as narratival conversation partners in society, and studying one can reveal the complexity inherent in the other, in a given social context. To return to the example of Lincoln, one can probe or contest certain narratival aspects of his story (e.g., What exactly drove his desire for the abolition of slavery? Ethics or morals? Economics? Political gain?), thus reshaping our understandings of his presidency and its legacy; but the story is only malleable to a certain extent (e.g., one could not successfully argue that Lincoln was opposed to the U.S. Constitution's Thirteenth Amendment). Asking such questions informs a history of Lincoln, Civil War politics and its outcomes, but may also provide insights into how society, historians included, have remembered him and his accomplishments, in various times and places, and for what purposes.

Similar questions may be asked of the Hebrew Bible, especially in relation to thinking about the Bible itself as a collection of historical discourses, and how its books may have been received as such in antiquity. In other words, are the 
books now contained in the Bible ancient histories of some kind? What might these books tell us about the literary culture and social remembering of the Israelites or Judeans who produced and maintained them? And how might one go about using these books to write history today? Approaching the issue of Lincoln and the political history of the Thirteenth Amendment, for instance, scholars stand on relatively solid ground in their historical debates, since Lincoln's era falls within the bounds of our own historical time, during which the facts of the past have been amply documented by persons and groups in a variety of institutional settings. ${ }^{31}$ The Bible's books, though, come from a time and place for which documentation - that is, historical evidence-is scarce. Moreover, the literary culture in which and by which the books emerged was notably different from our own. These books, ancient Judean artifacts as it were, contain discourses that are clearly multivocal, and thus are unlike typical literary discourses, including histories, today. ${ }^{22}$ In most narratives, the "system of emplotment" (the logic that unites a narrative's events within a temporal framework) works toward a meaningful telos for the reader (Ricoeur 1984-1988: 1.65-68). Multivocal narratives, like those found in the Bible, however, often lack a strong sense of ending; they contain extensive instances of peripeteia (the falsification of a narrative expectation, another Aristotelian concept), which lead to overdetermination (Kermode 2003: 18-22). ${ }^{33}$ Many of the Bible's narratives, especially in the so-called historical books (e.g., Joshua,

31 The amendment was ratified in 1865 , forty-one years after Ranke published his famous dictum concerning what "actually happened" in history. By Lincoln's time, the modern historical condition or "regime" (Hartog 2015) was fully present. The quantity and even quality of documentation from the previous two centuries, however, does little to quell intense disagreements about particular details of modern history.

32 Diachronically speaking, one can account for the apparent multivocality in the literature by positing different compositional hands or stages over long periods of time. There is little doubt that the literature is composite, and that it brought together different sources and authorial voices in ways that did not always smooth out or reconcile the differences (see, e.g., Carr 2011 and Schmid 2012 for comprehensive treatments of the Bible's compositional history). This fact, however, does not address the question of how ancient Judean readers perceived such discourse, and how their perceptions of it contributed to their social remembering of the past, as that past was recounted in the literature itself. For an attempt to address this issue at length, and with regard to the concept of kingship in Judean discourse, see Wilson 2017.

33 An appropriate literary analogy here is Bakhtin's well known reading of Dostoevsky. Dostoevsky, writes Bakhtin (1984), "brought together ideas and worldviews, which in real life were absolutely estranged and deaf to one another, and forced them to quarrel" (91). James Wertsch (2009b; 2010) has recently argued, in the same vein, that Bakhtin's understanding of text as dialogical provides a useful heuristic for studying social memory in general. 
Judges, Samuel, Kings, Chronicles, among others), lack a resolute moment of anagnorisis, in the Ricoeurean sense of the term. And in these books, it is even sometimes the case that moments of anagnorisis, when they are present, are also moments of peripeteia. ${ }^{34}$

Biblical narratives about the past are overdetermined and consistently manage to undermine themselves. These books' multivocality and their complicated narrativity thus present significant challenges to any historian attempting to use them as sources for the ancient past. How should one handle the Hebrew Bible's accounts of monarchy, for example, which both praise and lament the institution of kingship, and how should one think about these texts vis-à-vis extra-biblical evidence of Israel's and Judah's kings? Or, what to do with a book like Joshua, which appears to blatantly contradict its own literary purposes, and which recounts events that do not align with what we know about the early Iron Age, the period in which those events supposedly occurred? What kinds of historical information might such an artifact contain about its ancient social and cultural contexts? Below, I argue that the multivocal narratives themselves can be subjects of historical inquiry and can provide valuable historical information about ancient Israelite/Judean culture and its concerns, regardless of the historicity of the persons and events described therein. ${ }^{35}$

\section{Part 2: Hebrew Bible and History}

The Bible would make a fascinating historical source, if only we could figure out how to use it as such.

FLEMING 2012: 3

At least two main questions confront scholars interested in the Hebrew Bible and history. First, are there texts in the Bible that qualify as history; in other words, can we speak of these texts as historical in some way, in their ancient context? And second, can we use these texts, today, in combination with other sorts of evidence, to compose history; that is, to write about the history of ancient Israel and Judah and the peoples with whom they interacted? How one answers the first question will, of course, affect how one approaches the second. Over the last thirty years or so, among Hebrew Bible scholars, these

34 The institution of kingship in Israel, as represented in the books of Judges and Samuel, is a striking example. See Wilson 2017: 77-130.

35 Special thanks go to my friend and colleague Andrew Tobolowsky, who read a draft of Part 1 and provided helpful feedback. 
questions have been fuel for heated debates between so-called "minimalists" (those who "generally distrust the Bible's account of Israel's past") and socalled "maximalists" or "non-minimalists" (those who "find value in the Bible's accounts of Israel's origins and may adopt the Bible's basic timeline and paradigms as frameworks for their own history writing endeavors"; Moore 2006: 1-2). The debates and associated issues are not as simple as this dichotomy of labels might initially suggest. These days, moreover, the labels are typically used as pejoratives, lacking any real explanatory function. As Megan Bishop Moore (2006) has demonstrated, most so-called "maximalist" scholars have incorporated "minimalist" ideas into their work (cf. Grabbe 2007: 23-24). Nearly all historians of ancient Israel and Judah approach biblical texts with a critical eye, seeking to determine if and how any particular text might contribute to an understanding of ancient history (although what scholars end up doing with any given text varies widely). In the discussion below, therefore, I avoid making direct reference to "minimalists" or "maximalists," the debates of which are amply documented and have been discussed at length elsewhere. ${ }^{36}$ I will, instead, comment on the challenges of these two fundamental questions, focusing on the early Israelite monarchy and historical evidence for it, as a primary exemplar, in order to introduce and review some current historical research in biblical studies-research that is founded upon these questions but has moved beyond the "minimalist/maximalist" debates of previous decades.

\section{$1 \quad$ Is the Hebrew Bible Historical?}

Many scholars are comfortable referring to books like Joshua, Judges, Samuel, Kings, and Chronicles as ancient history-writing, that is, as generically historiographical books in their ancient contexts. Defining ancient historiography as a genre, however, is no easy task (Wilson 2017:19 n. 33; cf. Barstad 2008: 1-45; Pioske 2015a: 8-62). Consider, for example, the following definitions of historiography, with regards to the Hebrew Bible: (1) "narrative that presents a past" (Brettler 1995: 12; cf. 2014: 15-16); (2) writings that "purport to be true, or probable, representations of events and relationships in the past" (Halpern 1988:6); (3) ideological articulations of "national identity and the origins of customs and norms by which the society is to live" (Van Seters 2009: 353; cf. 1992: 24-42, 86-99); and (4) "stories containing descriptions of past events in sources used for historical reconstruction” (Barstad 2008: 39). The Bible certainly contains narratives that describe and represent pasts, and also narratives that articulate national identities and social origins. Classical and modern historiography

36 See, e.g., Moore 2006; Grabbe 2007: 3-36; and Moore and Kelle 2011: 1-42, for accounts of the relevant issues and scholarship. 
share these concerns, too. History-writing in general provides readers with accounts of "politically significant happenings in the past" (Pitcher 2009: 11), and it is interested in "coming to grips with temporality" (Grethlein 2013: 6) - that is, consciously seeking to achieve a re-experience of past time.

Where scholars run into problems is when they try to discern the relationship between such accounts, the data used to construct them, and any authorial intentions behind these constructions. For classical historiography, for example, our knowledge is limited, but we do have some idea about how Greek and Latin writers constructed accounts and how they theorized about such constructions (cf. Pitcher 2009: 14-24). We have no explicit evidence, however, for this sort of second-order thinking about historiography in ancient Israel or Judah. We must always consider the likelihood of significant differences between historical epistemology in ancient Israel and Judah, in other ancient locales, and in our own era (cf. Hendel 2005: 95-107). Daniel Pioske (forthcoming 2018), for example, whose research I discuss in more detail below, has worked toward a more sophisticated understanding of the ancient literary culture that produced the texts now contained in the Bible, identifying different modes of remembering that would have informed the production of Hebrew prose narratives about the past. By examining ancient Hebrew narratives that represent the early Iron Age (but which were written down later) and considering them in light of early Iron Age archaeological data, Pioske demonstrates how the dynamics of social remembering among ancient Hebrew scribes is largely incommensurate with historical epistemology today. ${ }^{37}$ On account of this difference, Pioske is cautious about using the term "historiography" in his cultural-historical investigations of ancient Hebrew texts.

Recognizing these significant issues, I nevertheless find the category "historiography" useful for discussing some of the Bible's literature, especially given the fact that our own epistemology of history is widely disputed. Applying the tag of "history" or "historiography" to any text, ancient or modern, has its generic and philosophical problems. Today, the distinction between, say, historiography and historical fiction might be clear enough (keeping in mind Ricoeur's comments on "the documentary moment" and "presumed truth" in professional historical discourse, outlined in Part 1), but there is remarkable diversity in each of those respective categories. Note, for instance, the difference between what qualifies as a doctoral dissertation in a university's history department and what is sold under the rubric "history" or "non-fiction" at any given bookstore in North America. A doctoral dissertation on the American 
Civil War and a trade paperback covering that same event may both be labelled "history" or even "historiography," but each is held to significantly different standards by its respective readerships.

In any case, the point is that the classificatory boundaries are blurry. Genre is never static or monolithic. By claiming, with others, that texts like Samuel or Kings are somehow historiographical, I am not excluding the possibility that they are also, at least in part, mythic, folkloristic, didactic, poetic, commemorative, and so on (cf. Hendel 2005:104-105). The title of a recent essay by Rachelle Gilmour, "(Hi)story Telling in the Books of Samuel" (2016), nicely illustrates this point. Following the insights of Jacques Derrida and others, I reiterate that texts do not belong to genres; they participate in generic economies (Wilson 2017: 223-34). Historians should "read these ancient texts on their own terms ... taking seriously the textual plurality in which they exist and the multiformity found within them individually and between them collectively," as Raymond Person states in a recent contribution (2016:82). The multivocal and multiform nature of the biblical texts makes them unlike modern historiography, which typically relies on rigorous evidentiary documentation and is more consistent in its generic forms, but the biblical texts are, nonetheless, at least partly historiographical in their representations of the past. They demonstrate an interest in accounting for the community's supposed real past (as opposed to any blatantly non-real past) via prose narrative, and so qualify as a kind of history.38 Person, for instance, therefore maintains the label "history" for Samuel, Kings, Chronicles and the like, but qualifies it as "traditional history"; that is, history rooted in a predominantly oral culture, which, in its production of prose narratives about the past, draws on and preserves a variety of forms and genres typically prevalent in cultures predominated by oral story telling. Person's approach is similar to Pioske's in that it recognizes the different cultural dynamics at play behind the formations of historiographical narratives in the Bible. The epistemological foundations of the Bible's historiographical texts, then, may be more akin to the practices of social remembering than to the documentary

38 Cf. Brettler 2007: 307-308. In protest, some scholars might mention books like Ruth or Esther, which also purport to represent a real past in prose narrative form, but which are apparently not historical. Esther, for example, communicates the fact of the Persian empire and the Jewish diaspora within it, but its narrative, which abounds with satirical humor, making a mockery of Persian rule, is clearly non-historical in its specific details (cf. Levenson 1997: 23-27). I would counter by emphasizing, again, that the biblical texts belong to no single genre. Esther has the appearance and even some of the elements of historiography but is in fact much more comical than historical, while Kings, for instance, has more pronounced historical interests and features even as it contains legendary and propagandistic elements. 
research of modern historians, but we may still speak of these texts as a sort of history-writing in their ancient setting.

\section{$2 \quad$ Can the Hebrew Bible Be a Source for History?}

If certain texts in the Hebrew Bible indeed qualify as a kind of history-writing, how can we utilize these ancient works to inform our own historical interests and endeavors? Take the Israelite monarchy as an example. The biblical texts are, of course, largely concerned with the stories of Israel's and Judah's kings: how the institution of Israelite kingship came to be in the land, how that institution split into two separate monarchies, and how eventually those monarchies were subjugated to and dismantled by Mesopotamian imperial forces. The books of Judges, Samuel, and Kings as well as Chronicles recount these stories in detail. Prophetic literature, too, addresses the issues of monarchy extensively, and kingship is a subject of focus in a number of psalms and in some wisdom literature to boot. Accounts of the monarchy, as a key feature of Israel's past, are ubiquitous in the Bible. And the accounts are, in large part, generically historiographical, as I stated above, demonstrating an interest in representing the real past for the purpose of re-experiencing that past time and maintaining a sense of socio-political identification with it (for better or worse, from the perspective of those reading these texts in Israel and Judah's postmonarchic era).

Until rather recently, it was commonplace in biblical scholarship to assume the basic plotline and details of these accounts as historical facts: Saul was the first king of Israel, a Benjaminite who reigned from that territory; he was replaced by the Judahite David, who moved the capital south to Jerusalem and whose son Solomon oversaw Israel's becoming a significant power in the region; the kingdom then split in two after Solomon's death, with Jerusalem remaining as one seat of power and the other seat being established in Samaria to the north; and finally the northern kingdom fell to the Assyrian empire while the southern kingdom lasted another century-plus before falling to the Babylonians. Widely read, and still cited, works by Martin Noth (1958 [German original, 1950]) and John Bright (2000 [original, 1959]), for example, more or less recapitulate this outline when they come to the Israelite monarchy. Even Gösta Ahlström's more recent historical work (1994), which at its time of publication was considered provocative, reads for the most part like an overview of the biblical accounts.

Concerning David, for example, Ahlström states as matters of fact that the Israelite king "began his career at Saul's court as the king's armor-bearer (1 Sam. 16.14)" (456); that "[a]fter a while David got a Philistine city of his own, Ziklag, where he and his entourage could settle (1 Sam. 27.6)" (459); and that 
"[h]aving secured his position in the Cisjordanian territories and broken the Philistine hegemony with their control over the trade route along the coast, David turned against his Transjordanian neighbors" (480); among other claims about Israel's favorite king that simply repeat points of plot found in the books of Samuel, Kings, and Chronicles. In their reconstructions of Israel's monarchic history, these works by Noth, Bright, and Ahlström, to cite just a few exemplars, function basically as detailed commentaries on the Bible's historiographical narratives, with philological and archaeological details supplementing a retelling of the Bible's main plotline, with only minor tweaks made to the stories here and there. This is not to say, however, that these works are lacking in historical-critical insight. In many ways, each made seminal contributions to historical scholarship of its day. My comments here are meant only to point out that, for most of our modern era, the historicity of the Bible's stories of kingship was essentially taken for granted.

But in recent decades historical understanding of the Israelite monarchy has changed dramatically. In the 1980 s and 9os, several prominent archaeologists-Israel Finkelstein chief among them-began revising their knowledge of the early Iron Age, the period during which kingship was established in ancient Israel, and alongside these archaeologists a number of biblical scholars began rethinking their positions on the monarchy's history vis-à-vis its representations in the biblical texts. ${ }^{39}$ Scholars could no longer take for granted the basic plotline and details of the Bible's narratives concerning the early days of Israelite kingship, as it became more and more apparent that Jerusalem and its environs was never the home to a vast and politically significant kingdom in the early Iron Age. The fortifications and palatial structures at places such as Hazor, Megiddo, and Gezer now seem to have been built later than the days of Solomon (contra 1 Kgs 9:15), and Jerusalem itself, in that same time frame, seems to have been a modest city with little if any connection to the broader region (cf. Finkelstein 2010). Indeed, the much discussed Karnak relief, which commemorates pharaoh Sheshonq I's campaigns in the Levant, does not mention Jerusalem or other major sites in its vicinity (or the name Judah or Israel for that matter), suggesting that perhaps this locale was relatively insignificant, or at least not a worthy subject of Egyptian propaganda in this instance, in the tenth century BCE. ${ }^{40}$ All this is not to say that

39 The number of publications on this topic is truly staggering. For good overviews see, e.g., Finkelstein and Mazar 2007; Grabbe 2007: 65-122; Moore and Kelle 2011: 145-265; Noll 2013: 215-59.

40 That said, prominent Philistine sites also go unmentioned in the relief, which is curious. It seems that, for whatever reason, the Philistine centers and the main Judahite sites fell outside the purview of Sheshonq's propagandistic interests on this particular monument. 
Jerusalem was not home to a monarchic polity of some sort in the early Iron Age; the point, rather, is that there probably was no wide-reaching "United Monarchy" based in Jerusalem in the tenth century, as the books of Samuel and Chronicles claim.

Now, the history of Saul and David and Solomon, that is, of Israel's early monarchy, is largely moot. It has become increasingly difficult to offer any kind of detailed account of these rulers' reigns and their interactions with the people of Israel and its neighbors, given what we now know about the sociopolitical organization and demographics of the southern Levant in the early Iron Age. The biblical narrative, which for most of the modern era was considered to be a fairly reliable historical source, these days seems highly suspicious.

Some scholars go so far as stating that these rulers and their kingdoms never really existed (e.g., Thompson 1999: 205-207). With Saul and Solomon at least, it is true that we have no extra-biblical evidence for their reigns, which complicates any historical claim about them. The same is not the case for David, however. In the early 1990s, in the very midst of archaeologists' and historians' revising the early Iron Age, researchers at Tel Dan unearthed fragments of a ninth-century вС E Aramean stele that refers to a "[kin]g of the house of David" (The very least, this find reveals that non-Israelites, specifically the Arameans to the north, recognized a Davidic polity of some sort, less than two centuries after David supposedly lived. It is reasonable, then, to argue that at some point prior to the ninth century there was in fact a David who had political power in the region. "What we can know about David epigraphically," writes Baruch Halpern (2011), "is that he was thought of as a dynasty founder, which in any other ancient Near Eastern context would mean that he was one" (213; italics added), a statement with which I agree. ${ }^{42}$ But this find, in and of

While Finkelstein and others argue that this is because of Jerusalem's insignificance at the time, some have pushed for the opposite, arguing that Jerusalem was left out because of its significance to the Egyptians at that time (e.g., Halpern 2010: 276; Knauf and Guillaume 2016: 81). But regardless of the reason for it, Jerusalem's absence on the relief problematizes the biblical accounts that represent this era. See, e.g., Grabbe 2007: 81-83 and LeonardFleckman 2016: 224-31, for further discussion and references.

For the editio princeps, see Biran and Naveh 1993 and 1995. There has been some debate over Biran and Naveh's initial reading of the inscription, but I am convinced, with the vast majority of scholars, that it is correct. See, e.g., Becking 2011: 16-18 and Leonard-Fleckman 2016: $215^{-23}$, for further discussion and references.

42 If scholars are inclined to defend David's historicity, it seems to me that the stele provides the best approach. Another path is to appeal to David's characterization in the books of Samuel and Kings, especially the texts found in 2 Samuel 9 to 1 Kings 2 -the so-called "Succession Narrative" or "Court History" - as evidence that he was in fact king of Israel. This latter approach makes the claim that, since these texts depict David as thoroughly flawed and thus fully human, they must have some basis in historical reality. Julius Wellhausen (1957 [German original, 1883]), for example, famously commented that this 
itself, cannot adequately support further historical reconstruction of Israel's early monarchy. It is not direct evidence for the king himself or for anything that he or his "house" might have done. We are left with a tension between the apparent reality of a Davidic polity in the early Iron Age and the apparent unreliability of the Bible's accounts of this polity's early era-yet another instance of the paradoxical interrelationship of historical fact and representation, of evidence and documentation of the past and history's "standing for" that past, as I discussed in detail in Part 1.

Scholars' claims about David and the early monarchy have thus become increasingly cautious in the last twenty to thirty years. Compare, for example, Ahlström's matter-of-fact quote about the beginning of David's career (above) with these statements from Axel Knauf and Philippe Guillaume's current history of Israel:

The biographical connection between Saul and David is mostly fictitious.... The stories about David were updated as late as the fourth century BCE as part of the continuing conflict between Judeans and Benjaminites. David was remodelled into a singer at the court of Saul, a person who could not help being successful, and who eventually marries the king's daughter despite the king's devious machinations....

KNAUF AND GUILLAUME 2016: 72

passage stands as an excellent historical account because it "frequently affords us a glance into the very heart of events, showing us the natural occasions and human motives which gave rise to different actions" (262; cf. Von Rad 1966 [German original, 1944]; Halpern 2001; Baden 2013; among others). In this line of thought, it is argued that no people would ever invent such a flawed national hero (e.g., Baden 2013: 12). There are cases that directly contradict this argument, however. Ancient peoples did in fact create rather flawed heroes in their legends and foundation stories, even in the ancient Mediterranean and Near Eastern worlds. One thinks of the rape of the Sabine women, which is certainly a less than flattering depiction of Rome's legendary founder Romulus and his followers (see Livy, Ab urbe condita libri, 1.9; Plutarch, Romulus, 14). And of course there is the most famous ancient Near Eastern hero of all, Gilgamesh, who, according to the Epic, ruled as a tyrant in Uruk and regularly claimed jus primae noctis, leading to his encounter with the wild man Enkidu (see I.63-93 and II.103-15 of the Epic's standard version). Gilgamesh clearly had his problems as a ruler, according to the text. Yet on account of his fantastical escapades with Enkidu and his subsequent quest for immortality, he was remembered and revered for centuries throughout Mesopotamia. Gilgamesh probably was an actual king of Uruk in Mesopotamia's Early Dynastic period (mid third millennium BCE; see George 2003: 1.101-19), but his characterization and actions in the Epic do not in any way prove this. The same goes for David and his stories. The Tel Dan stele, to my mind, offers a stronger (and simpler) argument for David's historicity as a political leader in the ancient southern Levant. 
Given the developments in archaeological knowledge of the early Iron Age southern Levant, it is becoming commonplace for scholars to argue that the Israelite and Judahite monarchies were never really connected, at least not politically, and that the stories of Saul and David-now so intimately intertwined in the biblical book of Samuel — had completely separate origins and did not come together until centuries after the time when these persons would have lived. ${ }^{43}$ Instead of writing histories that recount David's beginnings in Saul's court and his eventual ascent to the Israelite throne, more or less recapitulating the biblical plot, scholars are now mainly considering the history of David's (hi)story; that is, how the figure of David was socially remembered in antiquity and what the narrative construction of his past life says about the later Judahite or Judean literary culture(s) in which and for which the David narratives emerged. ${ }^{44}$

Biblical scholarship has, therefore, largely moved away from detailed inquiries into the political history of the early Iron Age and toward an interest in the cultural history of the Bible's narratives. Why did the narratives take the forms that they did, and what sorts of meanings might have been produced in the composition and reading of these narratives in antiquity? To be sure, these kinds of questions have always been key components to historical-critical biblical scholarship, informing modern histories of Israel's monarchic era, but now they are often the primary object of historical inquiry rather than an interest supplementary to larger historiographical goals. In other words, in scholarship today, one would be much more likely to encounter, for instance, a historical study that explicates Bathsheba's import in ancient Judean culture-i.e., what society in and around the early Second Temple might have made of her story in its larger cultural context - than a historical account of her life in David's court in the early Iron Age.

The Hebrew Bible as a Source for Cultural History and Social Remembering

In the last few years, a number of scholarly works on David have appeared that exemplify this shift toward explicating the cultural history of the Hebrew

43 E.g., Van Seters 2009: 345-48; Blenkinsopp 2013: 36-41; Kratz 2015 (German original, 2013): 19-21; Wright 2014: 32-35; among others. Compare also the work of Daniel Bodi (2014), who argues that Saul and David were seminomadic "tribal chieftains" of their respective polities, and that the texts grew out of traditions about conflicts between these chiefs. Bodi's historical reconstruction of these chiefs' interactions, however, essentially follows the biblical story.

44 There is still a contingent of scholarship, however, that maintains the basics of the biblical storyline in its historical work (e.g., Provan, Long, and Longman 2015). 
Bible's narratives. Some efforts, like that of Mahri Leonard-Fleckman (2016) for example, still set their sights on the history of the early Iron Age, but in doing so they take a more sophisticated approach to the biblical material, recognizing its many disconnects with the sociopolitical realities of that time frame. Leonard-Fleckman's aim is to elucidate our knowledge of the complex relationship between sociopolitical identities named in the texts of the Bible and their historical referents, with "the house of David" being her main interest. The phrase occurs in the Tel Dan stele, of course, and throughout the Bible. While most of the biblical occurrences refer to the Davidic dynasty in Judah, there are several instances that appear to her to function differently (viz. 2 Sam 3:1; 15:16; 1 Kgs 12:16). According to her research, which also digs into Iron Age political nomenclature found in Assyrian texts, these instances refer to a kind of political support network, not to an established royal line or geographic seat of rule, and they represent the earliest understandings of the Davidic polity. She emphasizes, too, that these specific instances focus on the struggle to rule Israel, making no connections between David's house and the people of Judah per se. Thus, she argues, these texts suggest that David and his "house" ruled an "Israel" of the central highlands (apparently separate from Israel to the north) in the early Iron Age, and only later did Judahites "bookend" the texts with material that linked David with Judah specifically as a polity. 45

In her reconstruction, Leonard-Fleckman draws on (unpublished) insights from her mentor Daniel Fleming and another of Fleming's former students, Lauren Monroe (Leonard-Fleckman 2016: 7, 141, 170). Fleming and Monroe, it seems, while granting that north and south would have been distinct polities in the early Iron Age (as opposed to a "United Monarchy" as the Bible describes it; cf. Fleming 2012: 8-16), argue nonetheless that there was some sense of pan-Israelite identity during this period. They therefore describe the north as "Greater Israel" and the south as "Little Israel." This idea runs contrary to the thinking of many historians and archaeologists working on these issues, who would counter that things went the other way around. In other words, according to the counter view, already noted above, Israel and Judah were distinct polities and identities in the early Iron Age-i.e., there was no sense of connection between north and south - and only later, after the fall of Samaria under Assyrian imperialism, did Judah and its "house of David" take on any real sense of "Israeliteness." In any case, here we have an exemplar of the biblical texts informing an important historical debate around sociopolitical formations in the Iron Age, a debate that will no doubt continue with fervor in the years to come. Not all will agree with Leonard-Fleckman's (and 
Fleming and Monroe's) argument concerning the literary history's relationship to early Iron Age politics and identity. But her work provides a good example of current scholarship that is concerned more with the sociocultural conditions that produced the narrative and its peculiar details, and how those conditions relate to broader historical issues, than with the historicity of any events depicted in the narrative itself. Her work echoes efforts in the field of history that seek to unpack cultural and sociopolitical understandings in literary artifacts, and to bring those understandings to bear on other available historical data. Compare, for instance, Clifford Geertz's study of the negara in Bali (1980), and other such works noted in Part 1.

Another, similar effort is that of Daniel Pioske (2015a), but Pioske, instead of focusing on political nomenclature and identification in the biblical texts, examines the Bible's sense of place and its relationship with history. "Place," wrote Aristotle in his Physics, "does not perish when things in it cease to be" (IV.1). Pioske therefore examines the place of Jerusalem in the biblical and archaeological records, especially as it relates to David and social remembering of the king and his seat of rule. The general focus of his work, as discussed above, is to improve our understanding of ancient Israelite historical epistemology, that is, how Israelites or Judeans thought about their past, in order to illuminate our use of the biblical texts in historical inquiry. All too often, as Pioske outlines in another piece (2015b), biblical scholars adopt either a naïve historicism or an undue skepticism when it comes to the material in the Bible. His remedy for this is to develop a stronger framework for understanding how ancient historiography "stood for" the past in its indigenous literary culture (cf. Ricoeur; see Part 1).

Investigating Iron Age epigraphy and material remains alongside texts in Samuel, Kings, and Chronicles, Pioske "retraces" Jerusalem's representations in the texts, noting continuities and discontinuities between present knowledge of the early Iron Age locale, which he gleans from contemporary epigraphic and archaeological research, and the ancient knowledge of it, which he accesses through the texts. Rather than expending his efforts simply to date certain passages of text (e.g., this text seems to line up with this bit of archaeological data, ergo the text dates to that particular era), Pioske successfully strives to show how ancient composers of the literature wove together different memories of the city, memories that saw the locale as illustrious and ruined, as vast and miniscule, as stable and chaotic - and also how, in doing so, these composers seem to have excluded or forgotten certain details, filling in gaps and adapting memories when necessary. This process, he contends, was shaped by the history of the city itself. Pioske argues that the narrative accounts read and composed by the literati of ancient Jerusalem, in the Iron Age and later 
in the Persian period, mimicked the locale in which they were written, with its long history of ruling and being ruled, of wars won and lost, of peoples and institutions come and gone, remembered and forgotten. He demonstrates, for example, how narrative representations of geography, of urban social stratification, and of literacy in the Judahite capital, in Samuel-Kings, frequently reflect realities of the late Iron Age rather than the earlier periods in which the narratives situate them (2015a: 107-17). Memories were thus preserved within, perpetuated by, and adapted to the contours of the actual place at the time of composition. His work on the social remembering of David's Jerusalem has set the stage for a forthcoming monograph, Memory in a Time of Prose, that further elucidates our knowledge of ancient knowledge of Israel's past, and how scribes socially constructed that knowledge in their culture.

Alison Joseph's current work (2015a) is comparable to Pioske's, in that it seeks to improve our understanding of how ancient writers remembered their past, but her research is more expressly literary in its focus. Her primary concern is to explicate the cultural poetics of the Deuteronomistic writers of the book of Kings. ${ }^{46}$ She states outright that she does not read the book of Kings as a source for history (30). She is, however, doing historical work, in that she is recounting the historiographical methods of ancient Judahite scribes as part of their literary culture. Her study offers "observation-based criteria for determining intention [of the biblical writers]" (13), by pointing out what the writers chose to emphasize and deemphasize, how their selections interact with other literary traditions (e.g., prophetic stories), and how the organization of their compositions ultimately promotes certain ideologies. The writers of the book of Kings, she contends, consistently apply a "Davidic prototype strategy" in their remembering of the monarchic past. She writes, "This strategy illustrates a grand narrative scheme in which the most important players in history are connected, not only in their roles in history and their influence over the kingdoms of Israel and Judah, but also in their literary construction" (28). And the grand narrative scheme is organized around the notion that David was the ideal ruler, the cultic hero whose piety is the religious benchmark to which all should be compared. The goal was to do "what is right in the eyes of Yahweh," as David supposedly did.

As Joseph argues in her 2015 book and in another contribution $(2015 \mathrm{~b})$, however, David's portrayal in Samuel does not live up to the Davidic prototype

46 Joseph adopts Frank Moore Cross's position on the Deuteronomistic History and its formation, reading an initial composition from the time of Josiah, in the late seventh century вСЕ, and then a subsequent redaction that reflects the Babylonian conquest of Jerusalem (2015a: 20-24, 33-37). 
in Kings; that is, even David wasn't like David. This tension in the texts leads her to argue that "[the Deuteronomist] transforms the character of David, so well known from Samuel (or Samuel's sources), into a figure who is programmatically useful to him in his goal of writing a theologically based, cultically focused history" (2015a: 226).$^{47}$ Her project thus seeks to recount historical developments in Judahite thought and culture by theorizing about literary history via close reading of the texts. This kind of approach is not "new" per se; indeed, it is the bedrock of modern historical-critical analysis of the Bible. But Joseph's implementation of the classic historical-critical method nonetheless builds upon the insights of recent developments in historical inquiry. In her discussion of poetics and the import of narrativization, for example, she draws directly on Hayden White (2015a: 15-19, 53-58). And although she does not address the issue of memory or remembering directly, Joseph's work is complementary to the research of Mark Smith (2004) and of her mentor Ron Hendel $(2005 ; 2010)$, both of whom incorporate theories of social memory into their tradition-historical analyses of biblical texts. ${ }^{48}$

The three works just outlined take a diachronic approach to the texts; that is, they read the texts as evincing historical development over time, attending to the shifts and disjunctures in the texts and attempting to account for such shifts by theorizing about compositional history and its relationship to sociopolitical and cultural developments in the Levant, in the Iron Age and later. Others take a more synchronic approach that is nonetheless historical, in that it situates the texts as compositions within a particular time frame, and then uses them as a source of knowledge for the sociocultural context responsible for the compositions, as it were.

A prime example of a more synchronic approach is Diana Edelman's essay (2013) on the social remembering of David in the late Persian and early Hellenistic periods. This is the era during which the books of Samuel and Kings, and subsequently Chronicles, likely emerged as works of literature with some amount of authority for their Judean readers. ${ }^{49}$ With David, it has long

47 John Van Seters (2009), notably, argues basically the opposite about the material in Samuel and Kings, that the Deuteronomist's original, mostly lionizing account of David was rewritten in the Persian period to present a more problematic character, transforming the pro-David texts into a complex "saga" about Israel's most famous king and his dynasty.

48 Joseph Blenkinsopp (2013) and Jacob Wright (2014), too, have each produced works that are founded upon a classic historical-critical approach to the texts, but which effectively incorporate recent insights from memory studies to advance our knowledge of how peoples thought about David as part of their pasts, in the ancient Levant.

49 Edelman takes methodological cues from her colleague and collaborator Ehud Ben Zvi (e.g., 2014; 2016a). Cf. also Davies 2008. 
been observed that there are different ideas about his dynasty, its victories and failures, its hopes and disappointments, preserved in the books of the Hebrew Bible. Again, these books are clearly multivocal. The book of Samuel, for instance, promises that the dynasty will be established "forever" (עד עולם; 2 Sam 7:13, 16) and Kings presents David as the royal benchmark, Israel's prototypical ruler; and yet the dynasty comes to an end that one might call embarrassing, with the last Judahite monarch ironically elevated to a position of status in Babylon, not Jerusalem, under the aegis of a less than noteworthy Babylonian king (2 Kgs 25:27-30; cf. Wilson 2014). Whereas diachronic approaches would situate each of these different ideas about David in a specific time and theorize about how they came together, a more synchronic approach asks what it might have meant for Judean literati to read and promote literature that juxtaposes these ideas in a certain way, and what such juxtaposition might indicate about Judean culture and its understandings of the monarchic past. In relation to David and the tangled web of texts and discursive potentials associated with him, Edelman argues that—for ancient Judeans reading these texts in the context of early Second Temple Jerusalem-remembering David as a pious figure who recognized his mistakes, and who remained devoted to Yahweh in the face of it all, helped mitigate the problem of the dynasty's collapse and exile. In this way, David was thought to have been a kind of everyman who epitomized a successful life lived before Yahweh, despite one's victories and ultimate failures. ${ }^{50}$

My own recent work (Wilson 2017), in similar fashion, argues that ancient Judeans were able to maintain these diverse and even contradictory memories of David, and the various memories of Israelite and Judahite kingship in general, on account of prophetic literature's diverse understandings of the Davidic dynasty's future. In other words, ancient Judean culture allowed for and even perpetuated a multivocal discourse on Israel's monarchic past, especially in relation to its foremost king, because it simultaneously imagined a variety of possible futures for the institution of monarchy. This kind of work takes up the problem of David, the Hebrew Bible, and history from a different angle than the diachronically focused works outlined above. Instead of asking how the diversity of views in the biblical texts came to be, and what cultural contexts might have produced those various views over time, it asks: What does the fact of textual diversity in the Hebrew Bible's books say about the society and culture that produced and read such books in antiquity? Each approach is valuable, and has furthered our historical knowledge of David, the books of

50 Compare how Americans have variously remembered Abraham Lincoln in the twentieth century (see Schwartz 2000; 2008; discussed in Part 1). 
the Hebrew Bible that speak of him, and the cultures in which and for which the ancient texts emerged.

It is a fact, a "singular existential statement" (to use Hayden White's phrasing), that David was recognized as the founder of a polity in the Iron Age Levant. It is a fact that Israel and Judah had monarchies. The Tel Dan stele and Assyrian records tell us as much, and the Bible does not disagree. Thus our historical explorations of biblical texts along these lines have at least some firm ground on which to stand. Scholars like Leonard-Fleckman, Pioske, Joseph, and Edelman-each discussed above-have made noteworthy contributions to our historical knowledge of the Israelite monarchy, specifically to our knowledge of how the biblical writers narrativized and remembered this institution and its most prominent king, David. And, furthermore, this scholarship allows us to examine how these later narrative constructions of the past compare to the apparent realities of the Davidic polity and its environs in the early Iron Age. In this case there is a plethora of historical issues and approaches to such issues that the historian may take up. But what about other historiographical texts in the Bible whose foundations in ancient historical reality are not so firm? What about texts that make seemingly historical claims about obviously ahistorical matters? Can we still "do history" with texts describing events and persons that have no apparent factual basis? Can we still pursue historical inquiries that relate to Joshua's conquest of Canaan or Ehud's slaying of Eglon the Moabite, to offer a couple of examples? I argue that we can. But our historical work, in these cases, would not produce accounts of Joshua's victories or of Ehud's judgeship. The Bible already contains such narrative representations. Our work would, instead, interrogate the texts as sources for the cultures in which and for which they emerged as literatures, thus strengthening our historical understanding of ancient Israelite or Judean society and life, much like recent works on David and the Israelite monarchy have done.

\section{Part 3: Joshua, a Historical Take}

The comprehensive conquest saga in the Book of Joshua is a fictive literary composition.... Military events that took place in the course of the later history of Israel were used by the author as models for his narratives. These military episodes were entirely adapted to the new environment so that in no case can we trace a direct literary relationship between the original story/tradition and its literary reflection.

NA'AMAN 1994: 280-81

BRILL RESEARCH PERSPECTIVES IN BIBLICAL INTERPRETATION 3.2 (2018) 1-69 
What is a historian to do with something like the book of Joshua? ${ }^{51}$ Although there continues to be considerable debate about the book's history of composition and related issues, many scholars today, including myself, agree with the above statement, from historian Nadav Na'aman, that the text is a literary fiction. The book's narrative may indirectly reflect ancient vestiges of the collapse of Levantine urban life during the late Bronze/early Iron Age, as Na'aman himself and others have argued (cf. Stone 2014), but there was certainly no Israelite "conquest of Canaan" as this particular book would have it. The text, then, in and of itself, has little value for historical reconstructions of the late Bronze or early Iron Age. That said, in this brief exposition, I want to salvage the book of Joshua for historical research. The book may be a literary fiction, but it is a historical source nonetheless-it is a literary artifact that we can investigate for insights into the social remembering of the ancient culture in which and for which the book emerged. The book is, therefore, perhaps not very good for questions of traditional political history, for which it was frequently used in nineteenth- and twentieth-century scholarship, but it may be very fruitful for current questions related to the cultural history of ancient Israel and Judah.

In my brief comments here, I do not make any specific historical argument per se; instead, I outline some possibilities for using the book in contemporary historical research, ultimately promoting an approach that focuses on questions of social memory, an approach that sees the text's apparent disjointedness and narrative difficulties as invitations to ask questions about its primary ancient readership and their culture. In a recent contribution to the question of theology in the Bible, Dalit Rom-Shiloni (2016) makes a statement that is helpful, as a starting point: she writes, "The Hebrew Bible demonstrates the alertness of different authors (at times relatively synchronic) to diverse literary options for describing God ... but these authors differ in their perceptions of the limits and restrictions that may be applied to the literary portrayal of God" (177). This statement applies to most concepts found throughout the Bible's literature. Indeed, if one replaces Rom-Shiloni's references to God with references to Israel's entry into the land, the statement still rings true. Here it is again, but this time in terms of the land: The Hebrew Bible demonstrates the alertness of different authors (at times relatively synchronic) to diverse literary options for describing Israel's entry into the land, but these authors differ in

51 A draft of Part 3 was presented in San Antonio at the 2016 Annual Meeting of the SBL. The presentation was part of a special session concerning the book of Joshua and historical research, hosted by the "Current Historiography" program unit. Thanks go to my fellow panelists for their keen insights and to those in attendance who provided helpful feedback. 
their perceptions of the limits and restrictions that may be applied to the literary portrayal of Israel's entry into the land. The interesting thing here, to me, is not that the literature contains different perspectives-this goes without saying for critics of the Bible. What interests me is that the literature evinces a mindset that is alert to these various viewpoints. There are preferences for certain points of view, within certain literary limits, but the larger literary context demonstrates a way of thinking that embraced disjointedness and discontinuities in order to form coherent and authoritative discourses, even within individual texts like the book of Joshua.

Now, to be sure, others have adopted similar ways of thinking about the literature of the Hebrew Bible and about the book of Joshua in particular, but here I would like to lay out my specific approach to this text and these issues. To borrow a term from recent interpretive anthropology and sociology, how were "grey zones" (cf. Bonner 2009) created in readings of the text? Where and how would textual discontinuities come together to foster potential continuities and coherences, that is, possible meaning-makers for ancient readers of this book? And what does this tell us about the culture of the society that produced, read, and promulgated such literature in the ancient world? What we will see is that the text's ambiguities and ambivalences, the points at which the discourse becomes convoluted and the picture fuzzy, are the points that would likely foster meaning for its culture. Thus, I take for granted the composite and somewhat disjointed nature of this text—as would the text's ancient readers - and so, instead of asking how it became composite or what its various parts say about different supposed historical authors or eras, I ask what its apparent disjointedness might say about the literary culture that received and accepted it as such. The kinds of questions that interest me may not be the classic historical-critical questions that have been asked of Joshua-e.g., what might this text tell us about the emergence of Israel in the ancient Levantbut they are historical questions nonetheless. I am interested in historical communities and cultures, specifically in the ancient Judeans of the early Second Temple era, who, as far as we can tell, were responsible for constructing many of the discourses now contained in the Hebrew Bible. And thus I am interested in reading the book of Joshua as a source for the cultural history of this society and era.

In what follows, then, I would like to comment on several aspects of the book of Joshua that I think deserve attention in relation to the approach I have sketched here. First, I will briefly comment on the book's date, textual history, and location, since an approach like the one I am advocating is not possible without situating the text in a particular place and time. Second, I will comment on the book's coherence despite its disjointedness, the fact that it holds 
together as a book despite its discrepant claims about the success of Israel's entry into the land and so on. ${ }^{52}$ Here, the devil is in the details, so to speak. Examining how the book holds together and then where and how its discontinuities fit into and work within its apparent coherence is key for understanding how the book would shape social memory in the early Second Temple era. And finally, to give an example of this sort of understanding, I will comment on the specific problem of success in the book, on the issue of whether or not the land was actually fully conquered and emptied, and how this would relate to remembering the figure of Joshua himself as a leader of Israel.

First, to situate the text. I am in agreement with a significant group of scholars who see the book of Joshua as a text that emerged in Israel's postmonarchic era, during the early Second Temple period. There is, to be sure, substantial debate concerning the text's prehistory, its compositional development, how different sources might have come together and/or been revised or redacted over the course of time, in order to form the book as such..$^{53}$ But a number of scholars-each of whom have very different ideas of the text's compositional history-agree that the book of Joshua emerged in the early Second Temple era, as part of or at least closely related to an emergent collection of Judean historiographical literature. ${ }^{54}$ That said, it is important to emphasize, however briefly, that there were multiple instantiations of this book in that era. We know from the Old Greek and from Qumran that different versions of the text circulated in antiquity. There are subtle but important differences between the Masoretic text and the Septuagint, differences that would effect various understandings of the book's interrelationship with other books in the Judean corpus - the Septuagint's version of Joshua, for instance, demonstrates closer ties to the book of Judges than does the Masoretic version of Joshua (cf. Dozeman 2015: 37-43). Keeping in mind the pluriform nature of this text in the ancient world, my comments here will be necessarily broad, covering only general discursive issues that we can confidently locate across the ancient versions.

So, if chronologically the text is early Second Temple, where are we to locate the text geographically? As scholars often emphasize, the book has a kind of "northern" focus. Joshua, the people's leader, is an Ephraimite. The

$5^{2}$ On the concept of coherence in relation to biblical texts, see Brettler 2010.

53 On the challenges of dating biblical texts see, e.g., Sommer 2011, who discusses problems with connecting dates and meanings, and with the lack of methodological controls for assigning dates to particular texts. He aims his critiques primarily at those who date biblical texts to later periods, but his concerns are valid for any attempt to date the texts.

54 See, e.g., the Introduction in Dozeman 2015, with detailed discussion and further references. 
book presents Shechem and the nearby mountains Ebal and Gerizim-in Manassehite territory — as a central place of meeting and worship. Moreover, it allows for worship at peripheral sites (e.g., the altar in the Transjordan; Josh 22:11-34 $)^{55}$ and has an overall inclusive view of the northern tribes in its account of territorial allocation. It also homes in on the liminal territory of Benjamin, in the space between north and south, relaying lengthy narratives about Jericho, Ai, and Gibeon-locales that either fall within or have close ties to that territory. Although Jerusalem and Judah are present in the text, the book presents a kind of "pan-Israel" perspective, mostly from a northern point of view.

When we talk about the book of Joshua as a literary artifact, then, we are talking about a text that represents a particular cultural discourse in ancient Israel: that is, it is a postmonarchic text that speaks to issues of worship and land, of obedience to Yahweh and how to account for a range of geopolitical issues - what land is fully Israel's and what is not, where is it okay to worship, and how did the events unfold that led to these issues in the first place?

In relation to these questions, it is insightful to consider where we find apparent coherences and continuities within the discourse, and where there are areas of noticeable disjunction, of discontinuity and tension in that same discourse. Here I mention a couple of major examples of continuity that would lend themselves to discursive coherence: (1) the recurring theme of Yahweh as the people's divine warrior (e.g., 10:14; 23:10; cf. Nelson 1997: 14); and (2) the book's repeated insistence upon Torah obedience (e.g., 1:7-8; 8:34-35; 22:5; 23:6; cf. Nelson 1997: 20). Throughout the text Yahweh fights for the people. Even though Joshua is appointed as leader, and in some cases he indeed demonstrates his mettle, it is the deity who is ultimately responsible for any victory; the text leaves no doubt about this (cf. Wilson 2013: 317-20). Furthermore, the deity's willingness, as it were, to succeed on Israel's behalf is dependent upon the people's obedience to divine instruction, to Torah.

That said, within this apparently coherent message, where might one find tension? Where would the text create "grey zones," conditions for possible ambiguity and even aporia in the minds of its readers, in relation to these overarching and consistent themes? In the book of Joshua there is at least one glaring tension: according to some statements in the book, Israel took control of the whole land (e.g., 11:23); and yet, according to other claims therein, they did not

55 Cf. Axel Knauf (2013: 119; also 2014: 83), who argues that, in the early Second Temple era, sites outside Jerusalem (e.g., Gerizim, Idumea, Elephantine) were acceptable as long as they were understood to be models of the Jerusalem temple. Joshua 22 would have contributed to such an understanding. 
(e.g., 13:1; cf. 23:1-13). In attempts to reduce this tension, scholars have argued that any claims of total conquest were not to be taken literally; the claims were, instead, part of an ancient literary trope, hyperbolic statements that should be taken with a grain of salt. Similar statements of complete conquest are common in other ancient Near Eastern accounts (cf. Younger 1990: 245-47). In the book of Kings, too, for example, there is a comparable juxtaposition of success and non-success: in 2 Kgs 24:14 we read that Nebuchadnezzar exiled all of Jerusalem, all its leaders and warriors, even though the subsequent narrative in 2 Kings indicates that all the city's leaders were not, in fact, taken away. ${ }^{56}$ There is good reason, then, to believe that ancient readers did not take Josh 11:23, for instance, too seriously. How could they, given the repeated emphasis on Israel's failure to secure the land? This argument is, however, not really a solution to the overarching problem. Even if 11:23 is removed from the equation, even if it is written off as literary hyperbole, contradictory claims still persist throughout the narrative. With the book of Joshua, we are not dealing with just one or two hyperbolic claims; we have, instead, an entire book whose literary framework relies upon the idea that Joshua will fully conquer and empty the land. Consider, for instance, the book's opening lines, in which Yahweh himself claims that no one will be able to hinder Joshua's success. In Josh 1:4 the deity even gives specifics about the extent of territory to be conquered by Moses's appointed successor. And yet the book emphasizes that this fails to happen. In the book of Joshua, there is a thoroughgoing undecidedness about the success of conquest.

As Ovidiu Creangă argues, drawing on contemporary spatial theory, ${ }^{57}$ the tension between the success or non-success of Israel's entry in to the land is a distinctive feature of the book's narrative. The tension "interrogates the central claims of the conquest narrative ... but also transforms the binaries [of identity] (Israelites versus Canaanites) with which the narrative operates" (Creangă 2016: 176; cf. Hawk 2000: xiii and passim). The Canaanites' remaining within the land impacts the land's ongoing identification with the people of Israel. Yahweh's people do not in fact empty out the land, and thus it is not fully theirs, despite Yahweh's own claim in Joshua 1 that Joshua will successfully lead the people to occupy it. The text thus undermines the binary of Israelite and Canaanite as distinct identities, as Creangă states and as others have argued,

56 Cf. Ben Zvi 2016b. Dr. Ben Zvi kindly shared with me a draft of this paper, which is slated to appear in a forthcoming monograph, provisionally entitled Social Memory among the Literati of Yehud, to be published by De Gruyter.

57 In addition to Creangă's contribution, see Russell 2016, for an introduction to spatial theory in relation to biblical studies. 
and it also obviously undermines the concept of success itself, with regard to Joshua's mission. This observation is not a new one, of course, but it represents precisely the kind of ambiguity or blurred picture in the text that I think generates interesting historical questions concerning cultural history in ancient Israel, specifically concerning social remembering.

These sorts of ambiguities and multivocal statements abound in Judean literature, and are ripe for historical investigation concerning Judah's literary culture. The literature's representation of kingship, for example, discussed in Part 2, is an example worth mentioning again. Elsewhere, I have examined the many issues related to kingship as a concept in Judah's social memory, within the discursive horizon of the early Second Temple era-a horizon that included the emergent Pentateuch as well as the books we now call the Former and Latter Prophets (see Wilson 2017). Was dynastic rule a good thing or a bad thing? Was the king supposed to be involved in cultic activity or not? Was the Davidic line to be renewed in some way, or was it defunct, a relic of a failed monarchic past? The texts offer a variety of perspectives on these issues; they relay multiple statements that would have lent themselves to different answers. The historiographical literature's multivocality on these issues, its diverse recollections of the monarchic past, I argue, would have informed and balanced the diverse imaginations of Judah's future, which we find primarily in prophetic literature.

Now, thinking about the book of Joshua in particular and its multivocal representation of Israel's success in fully emptying and occupying the land, what can we say about Judean social remembering of these issues? The book gives us no firm indication of any precise answer, which in and of itself suggests that the postmonarchic Judean readers receiving this literature were comfortable with the debate; their mindsets were firmly situated within a framework for multivocal discourse about this very issue. ${ }^{58}$ If we think about Joshua vis-à-vis Judges, within the Judean repertoire of historiographical texts, we find further support for this suggestion. The two books are closely interrelatedsome scholars might even say codependent. ${ }^{59}$ The classic example is, of course, the apparent link between Josh 24:28-31 and Judg 2:6-9. And yet the books clearly contribute different statements to the discourse on successful leadership and conquest of land. They represent different perspectives on the questions of kingly versus non-kingly leadership, northern versus southern

$5^{8}$ Cf. David Jobling's similar comments with regard to the book of Samuel (1998: 19); and see also my discussion of the modeling processes of social memory, in Part 1.

59 E.g., Serge Frolov (2014: 91), who argues that Joshua is not "compositionally well-rounded," and cannot be read as a standalone piece. 
leadership, and centralized versus diasporic worship, to name a few examples. The texts are dialogic, juxtaposing viewpoints of certain subjects. Such juxtaposition is not uncommon in Judean literature, and thus tells us something about Judean social remembering and historical thought. Take Psalms 105 and 106, for example, which offer very different but nonetheless complimentary takes on Israel's history, and which were apparently received as such, sinceeventually, though much later-they were set side-by-side in the Psalter (cf. Newsom 2006: 223-24). Also, consider the fact that Judean readers maintained both Samuel-Kings and Chronicles, and that passages in Isaiah 40-48juxtapose different positions on the question of Israel's history and Yahweh's shaping of it (cf. Wilson 2016). Judean writers and readers were comfortable embracing multiple voices on particular issues. Their literature tells us as much, and we should take this seriously in our attempts to understand the cultural history of the early Second Temple period.

In a recent essay, Axel Knauf (2014) conducts a thought experiment that is helpful for thinking about the book of Joshua along these lines. What if we did not have this book? What if only Judges, Samuel, and Kings were extant as sequels to the narrative of the Pentateuch? In that case, we might conclude that Joshua, Moses's appointed successor, was thought to be a total failure with regard to his military duty, his task of completely emptying out the land for the people of Israel. It is only in the book of Joshua itself that there is any notion of Joshua's success in this regard. Moreover, as I have already emphasized, even within the book that bears his name, Joshua's success is not clear cut. The book successfully demonstrates that obedience to Yahweh is key, but it does not necessarily demonstrate Joshua's success in such obedience. In an essay that complements Knauf's contribution (both are contained in the same volume, Edelman 2014), Serge Frolov (2014) writes, "Joshua plays a central role in the Enneatuch's rhetorical strategy by serving as a primary demonstration that YHWH is serious about rewarding observance, above all by granting the people of Israel uncontested control of a land of their own ..." (95). However, Frolov goes on to argue that in the early Second Temple era this rhetoric was ironic. The people had not been obedient, but they found themselves living securely in their homeland nonetheless. In this way the book of Joshua might actually have impeded the authority of the Enneatuch's message about the necessity of obedience.

Why, then, did Judeans keep this book around, and why did they bother to integrate it so well into this collection of books? Both Frolov and Knauf suggest reasonable answers to this question. Frolov argues that Joshua provides a counter to David: Davidic hopes must have seemed "hopelessly outdated" by this time (99), while Joshua would have provided a non-dynastic hero who still 
did the work of a king (conquest, promulgation of law, etc.); and this narrative would have gained further traction post-Alexander (100). Knauf argues that the text presents a "theology of the Land" that would fit well in the Persian period: the representation of land distribution would have been in conversation with the Persian establishment of military fiefs (e.g., Idumea; 80-82). In any case, it is clear that Joshua serves as a kind of ballast that, through its multivocality, brings some stability to the Judean cultural discourses of obedience and disobedience, of successes and failures in securing the land, of Yahwistic worship at the center and on the periphery, and so on. Thus, Thomas Dozeman (2015: 42) refers to Joshua as an "intertext" that would help establish linkages between different bodies of literature and the various complementary and contradictory ideas contained therein.

It seems clear, then, that ancient Judean readers would have embraced the multivocality of the book of Joshua, its hedging in relation to Joshua and Israel's success in taking control of the promised land; and that its readership would have drawn on a variety of discursive statements in Judean literature which were in conversation with the statements contained in Joshua. Moreover, it seems clear that the book of Joshua represents a way of Judean thinking, in its cultural context, that focused first and foremost on the importance of Torah obedience and proper worship in order to ensure Yahweh's full-fledged support of the people, and that focused only secondarily on Joshua's successes as a military leader during Israel's entry into the land. Obedience to Yahweh and his Torah is the most coherent element in the text, while the failure of Joshua and Israel to empty and fully occupy the land is the most obvious element of discontinuity and tension in the discourse. Curiously, Ben Sira and Josephus, in later Second Temple-era texts, clearly present Joshua as a great warrior and general. ${ }^{60}$ These texts do not diminish the importance of Torah obedience, to be sure, but they represent understandings of Joshua's role that seem alien to the book of Joshua itself, in which the memory of Joshua's overall success is fuzzy, blurred, not well defined. This should not be entirely surprising, however-as I said at the outset, and as anthropological and sociological research has demonstrated, these "grey zones," the areas where the text hesitates and lends itself to indeterminacy, would function as the most dynamic potentials for creating meaning in the literary culture.

To conclude this final part of the essay, I offer some questions: Why would Ben Sira and Josephus contribute to the discourse in the ways that they did?

6o Cf. Farber 2016: 141-48, 200-22; also Ben Zvi 2016b. Contrast these texts with Pseudo-Philo, which portrays Joshua as a "Torah personality" (Farber 2016: 187). 
What were the historical and cultural conditions that made such statements possible, vis-à-vis the conditions of the book of Joshua's discursive contributions? Some scholars point to the impact of Alexander and a supposed renewal of focus on military heroes in the Hellenistic period (e.g., Frolov 2014: 101), while others submit that, since stories of military might tend to be very socially salient-i.e., military leadership often functions as an effective socializing tool-later writers could not but focus on Joshua as a great victorious hero, despite the fact that, in the book of Joshua itself, Yahweh is the real warrior, the real hero of the narrative (e.g., Ben Zvi 2016b). To these positions I would respond that, first of all, Alexander was certainly not the first military hero the region had known, and even though Judah was relatively quiet during the Persian period, the Persian Levant was no stranger to military action-Egypt was a recurring problem for Persian governance, and of course the Persians had to cross through Judah to get there. So I am not so sure that it was only in the Hellenistic era that Joshua's supposed military prowess would become salient in Judah's social remembering. In any case, these are historical questions that deserve historical answers, and I hope that my comments here have demonstrated how reading the book of Joshua can lead to such questions and even contribute to their answers.

\section{Conclusion}

Historiography (that is, "history" and "writing") bears within its own name the paradox - almost an oxymoron - of a relation established between two antinomic terms, between the real and discourse. Its task is one of connecting them and, at the point where this link cannot be imagined, of working as if the two were being joined.

DE CERTEAU 1988: XXvii

The Hebrew Bible contains an abundance of discourse from ancient Israel and Judah. It is, thus, for us, an access point to a real past, to the historical societies and cultures responsible for its texts. There was a time, not too long ago, when scholars basically took for granted the historiographical process of the ancient composers of these texts, assuming that the production of these ancient discourses relied upon documentary moments not unlike our own, and that the composers' "as ifs" were apparent enough in the literature to afford us some access to the persons, peoples, and events described therein. This is no longer the case. Developments in archaeology and in our knowledge of the sociopolitical realities of the Iron Age Levant have significantly challenged the 
Bible's historiographical representations of Israel and Judah. But this is not a death knell for historical inquiry in biblical studies. It may no longer be possible to write a detailed history of David's rise to power and subsequent reign (without simply rehashing the narrative already present in the Bible's texts), but we can write histories that account for how and why the literati of Judah wrote about David the way they did, and what potential significance this writing would have in the literati's later social and cultural settings. It is, indeed, no longer possible to write a history of Israel's origins in the land that incorporates a sequence of conquests led by Joshua (or anyone for that matter), but we can write histories that detail the book of Joshua's import in later Israelite or Judean literary culture, relying on the book's multivocal narrativity to support reconstructions of literate thought patterns, and situating these apparent patterns in relation to the thinking about the past on display in comparable cultural discourses. With the case of David, our own "as ifs" may attempt reconstructions of the actual Davidic polity in the Iron Age, an entity for which we have some (admittedly scant) extra-biblical evidence. With Joshua, we are better off writing histories of the (hi)story. But in either case, and in others, the Bible remains ripe as a historical source for scholars in the twenty-first century.

In this essay, I have offered a view of how such a source might be cultivated. The books of the Hebrew Bible emerged within and for a literary culture in the ancient world. Their discourses are sources for this culture; that is, they speak to how certain meanings were made and promoted within the ancient society that produced and read the texts. Cultural historical approaches that draw on the concepts of narrative and social memory, as introduced here, are especially apposite to biblical studies. "[T] he Bible is a complex collection of historically embedded texts and textually embedded histories which cries out for a theoretically sophisticated scrutiny," once wrote Robert Carroll (1997: 302). An interpretive framework built around an attentiveness to the Hebrew Bible's narrativity, and to the possibilities of that narrativity's interplay with social remembering in an ancient Israelite/Judean context, it seems to me, provides a means by which to get at those histories embedded in the texts, and even, perhaps, to write history with them.

\section{References}

Adamson, W.L. 2002. "Marxism and Historical Thought," in Kramer and Maza 2002: 205-22.

Ahlström, G.W. 1994. The History of Ancient Palestine (ed. D. Edelman, with a contribution by G.O. Rollefson; Minneapolis: Fortress, 2d edn). 
Aichele, G. 2016. "The Play of Signifiers: Poststructuralism and Study of the Bible," Brill Research Perspectives in Biblical Interpretation 1.2.

Ankersmit, F., E. Domańska, and H. Kellner (eds.). 2009. Re-Figuring Hayden White (Stanford, CA: Stanford University Press).

Arnold, B.T., and R.S. Hess (eds.). 2014. Ancient Israel's History: An Introduction to Issues and Sources (Grand Rapids, MI: Baker Academic).

Assmann, J. 1997. Moses the Egyptian: The Memory of Egypt in Western Monotheism (Cambridge, MA: Harvard University Press).

Assmann, J. 2010. "Memory, Narration, Identity: Exodus as a Political Myth," in H. Liss and M. Oeming (eds.), Literary Constructions of Identity in the Ancient World (Winona Lake, IN: Eisenbrauns): $3^{-18}$.

Assmann, J. 2011. Cultural Memory and Early Civilization: Writing, Remembrance, and Political Imagination (Cambridge: Cambridge University Press [German original, 1992]).

al-Azmeh, A. 2014. The Emergence of Islam in Late Antiquity: Allāh and his People (Cambridge: Cambridge University Press).

Baden, J. 2013. The Historical David: The Real Life of an Invented Hero (New York: HarperOne).

Baker, C.A. 2011. Identity, Memory, and Narrative in Early Christianity: Peter, Paul, and Recategorization in the Book of Acts (Eugene, OR: Pickwick).

Bakhtin, M. 1984. Problems of Dostoevsky's Poetics (ed. and trans. C. Emerson, with an introduction by W.C. Booth; Theory and History of Literature, 8; Minneapolis: University of Minnesota Press).

Barstad, H.M. 2008. History and the Hebrew Bible: Studies in Ancient Israelite and Ancient Near Eastern Historiography (Forschungen zum Alten Testament, 61; Tübingen: Mohr Siebeck).

Barstad, H.M. 2010. "History and Memory: Some Reflections on the 'Memory Debate' in Relation to the Hebrew Bible," in P.R. Davies and D.V. Edelman (eds.), The Historian and the Bible: Essays in Honour of Lester L. Grabbe (Library of Hebrew Bible/Old Testament Studies, 530; New York: T\&T Clark): 1-10.

Becking, B. 2011. "David between Ideology and Evidence," in B. Becking and L.L. Grabbe (eds.), Between Evidence and Ideology: Essays on the History of Ancient Israel (Oudtestamentische Studiën, 59; Leiden: Brill): 1-30.

Ben Zvi, E. 2014. "Exploring Jerusalem as a Site of Memory in the Late Persian and Early Hellenistic Period," in D.V. Edelman and E. Ben Zvi (eds.), Memory and the City in Ancient Israel (Winona Lake, IN: Eisenbrauns).

Ben Zvi, E. 2016a. "Memory and Political Thought in the Late Persian/Early Hellenistic Yehud/Judah: Some Observations," in D.V. Edelman and E. Ben Zvi (eds.), Leadership, Social Memory and Judean Discourse in the Fifth-Second Centuries BCE (Sheffield: Equinox). 
Ben Zvi, E. 2016b. "Joshua as a Case Study for Constraints, Preferences, Balances and Flexibility within the Memory System of the Literati of the Late Persian Period," Presidential Address, European Association of Biblical Studies Annual Meeting, Leuven, Belgium, July 17 .

Biernacki, R. 1995. The Fabrication of Labor: Germany and Britain, 1640-1914 (Berkeley: University of California Press).

Biernacki, R. 1999. "Method and Metaphor after the New Cultural History," in Bonnell and Hunt 1999: 62-92.

Biernacki, R. 2005 (original, 2000). "Language and the Shift from Signs to Practices in Cultural Inquiry," in Spiegel 2005: 228-44.

Biersack, A. 1989. "Local Knowledge, Local History: Geertz and Beyond," in Hunt 1989: $72-96$.

Biran, A., and J. Naveh. 1993. "An Aramaic Stele Fragment from Tel Dan," Israel Exploration Journal 43: 81-98.

Biran, A., and J. Naveh. 1995. "The Tel Dan Inscription: A New Fragment," Israel Exploration Journal 45: 1-18.

Black, J. 2015. Clio's Battles: Historiography in Practice (Bloomington: Indiana University Press).

Blenkinsopp, J. 2013. David Remembered: Kingship and National Identity in Ancient Israel (Grand Rapids, MI: Eerdmans).

Bodi, D. 2014. "The Story of Samuel, Saul, and David," in Arnold and Hess 2014: 190-226.

Bonnell, V.E., and L. Hunt (eds.). 1999. Beyond the Cultural Turn: New Directions in the Study of Society and Culture (Berkeley: University of California Press).

Bonner, K. 2009. "A Dialogical Exploration of the Grey Zone of Health and Illness: Medical Science, Anthropology, and Plato on Alcohol Consumption," Theoretical Medicine and Bioethics 30: 81-103.

Boyer, P. 2009. "What Are Memories For? Functions of Recall in Cognition and Culture," in Boyer and Wertsch 2009: 3-28.

Boyer, P., and J. Wertsch (eds.). 2009. Memory in Mind and Culture (Cambridge: Cambridge University Press).

Braun, W. 2000. "Religion," in W. Braun and R.T. McCutcheon (eds.), Guide to the Study of Religion (London: Continuum): 3-18.

Braw, J.D. 2007. "Vision as Revision: Ranke and the Beginning of Modern History," History and Theory, Theme Issue 46: 45-6o.

Brettler, M.Z. 1995. The Creation of History in Ancient Israel (London: Routledge).

Brettler, M.Z. 2007. "Method in the Application of Biblical Source Material to Historical Writing (with Particular Reference to the Ninth Century BCE)," in H.G.M. Williamson (ed.), Understanding the History of Ancient Israel (Proceedings of the British Academy, 143; Oxford: Oxford University Press): 305-36. 
Brettler, M.Z. 2010. "The 'Coherence' of Ancient Texts," in J. Stackert, B.N. Porter, and D.P. Wright (eds.), Gazing on the Deep: Ancient Near Eastern and Other Studies in Honor of Tzvi Abusch (Bethesda, MD: CDL Press).

Brettler, M.Z. 2014. "Historical Texts in the Hebrew Bible?" in K.A. Raaflaub (ed.), Thinking, Recording, and Writing History in the Ancient World (Malden, MA: Wiley Blackwell): $213-33$.

Bright, J. 2000. A History of Israel (Louisville, KY: Westminster John Knox, 4th edn).

Bruner, J. 1990. Acts of Meaning (Cambridge, MA: Harvard University Press).

Burke, P. 2008. What Is Cultural History? (Cambridge: Polity, 2nd edn).

Bynum, C.W. 2009. "Perspectives, Connections, and Objects: What's Happening in History Now?" Daedalus 138: 71-86.

Carr, D.M. 2011. The Formation of the Hebrew Bible: A New Reconstruction (Oxford: Oxford University Press).

Carroll, R.P. 1997. "Clio and Canons: In Search of a Cultural Poetics of the Hebrew Bible," Biblical Interpretation 5: 300-23.

de Certeau, M. 1988. The Writing of History (trans. T. Conley; New York: Columbia University Press [French original, 1975]).

Chandler, D. Semiotics: The Basics (London: Routledge, $2 \mathrm{~d}$ edn).

Clark, E.A. 2004. History, Theory, Text: Historians and the Linguistic Turn (Cambridge, MA: Harvard University Press).

Cochrane, C.N. 1929. Thucydides and the Science of History (Oxford: Oxford University Press).

Confino, A. 1997. "Collective Memory and Cultural History: Problems of Method," The American Historical Review 102: 1386-1403.

Crane, S.A. 2002. "Language, Literary Studies, and Historical Thought," in Kramer and Maza 2002: 319-36.

Creangă, O. 2016. "The Conquest of Memory in the Book of Joshua," in Fewell 2016: 168-79.

Darnton, R. 1984. The Great Cat Massacre and Other Episodes in French Cultural History (New York: Basic Books).

Davies, P.R. 2008. Memories of Ancient Israel: An Introduction to Biblical HistoryAncient and Modern (Louisville, KY: Westminster John Knox).

Davis, N.Z. 1983. The Return of Martin Guerre (Cambridge, MA: Harvard University Press).

Davis, N.Z. 1997. "Religion and Capitalism Once Again? Jewish Merchant Culture in the Seventeenth Century," in Ortner 1997: 56-84.

Den Boer, P. 2010. "Loci memoriae — Lieux de mémoire," in Erll and Nünning 2010: 19-25.

Domańska, E. (ed.). 1998a. Encounters: Philosophy of History after Postmodernism (Charlottesville: University of Virginia Press). 
Domańska, E. 1998b. "Hayden White: Beyond Irony," History and Theory 37: 173-81.

Domańska, E., H. Kellner, and H. White. 1994. "Interview: Hayden White: The Image of Self-Presentation," Diacritics 24: 91-100.

Douglas, M. 2002. Purity and Danger (London: Routledge [original, 1966]).

Dowling, W.C. 2011. Ricoeur on Time and Narrative: An Introduction to Temps et Récit (Notre Dame, IN: University of Notre Dame Press).

Dozeman, T.B. 2015. Joshua 1-12: A New Translation with Introduction and Commentary (Anchor Yale Bible, 6B; New Haven: Yale University Press).

Edelman, D.V. 2013. "David in Israelite Social Memory," in Edelman and Ben Zvi 2013: 141-57.

Edelman, D.V. (ed.). 2014. Deuteronomy-Kings as Emerging Authoritative Books: A Conversation (Ancient Near East Monographs, 6; Atlanta: s bL Press).

Edelman, D.V., and E. Ben Zvi (eds.). 2013. Remembering Biblical Figures in the Late Persian and Early Hellenistic Periods: Social Memory and Imagination (Oxford: Oxford University Press).

Eley, G. 2005 (original, 1996). "Is All the World a Text? From Social History to the History of Society Two Decades Later," in Spiegel 2005: 35-61.

Erll, A. 2010. "Cultural Memory Studies: An Introduction," in Erll and Nünning 2010: 1-15.

Erll, A., and A. Nünning (eds.). 2010. A Companion to Cultural Memory Studies, with S.B. Young (Berlin: De Gruyter).

Eynikel, E., and T. Nicklas (eds.). 2014. Samson: Hero or Fool? The Many Faces of Samson (Themes in Biblical Narrative, 17; Leiden: Brill).

Farber, Z. 2016. Images of Joshua in the Bible and Their Reception (Beihefte zur Zeitschrift für die alttestamentliche Wissenschaft, 457; Berlin: De Gruyter).

Fentress, J., and C. Wickham. 1992. Social Memory (Oxford: Blackwell).

Fewell, D.N. (ed.). 2016. The Oxford Handbook of Biblical Narrative (New York: Oxford University Press).

Finkelstein, I. 2010. "A Great United Monarchy? Archaeological and Historical Perspectives," in R.G. Kratz and H. Spieckermann (eds.), One God-One Cult-One Nation: Archaeological and Biblical Perspectives (Beihefte zur Zeitschrift für die alttestamentliche Wissenschaft, 405; Berlin: De Gruyter): $3-28$.

Finkelstein, I., and A. Mazar. 2007. The Quest for the Historical Israel: Debating Archaeology and the History of Early Israel (ed. B.B. Schmidt; Atlanta: Society of Biblical Literature).

Fleming, D. 2012. The Legacy of Israel in Judah's Bible: History, Politics, and the Reinscribing of Tradition (Cambridge: Cambridge University Press).

Forsdyke, S. 2017. “Thucydides' Historical Method," in R.K. Balot, S. Forsdyke, and E. Foster (eds.), The Oxford Handbook of Thucydides (New York: Oxford University Press): 19-38. 
Friedlander, S. (ed.). 1992. Probing the Limits of Representation: Nazism and the "Final Solution" (Cambridge, MA: Harvard University Press).

Frolov, S. 2014. "The Case of Joshua," in Edelman 2014: 85-102.

Frye, N. 1957. Anatomy of Criticism: Four Essays (Princeton, NJ: Princeton University Press).

Gallagher, C., and S. Greenblatt. 2000. Practicing New Historicism (Chicago: University of Chicago Press).

Garber, M. 2013. "Jobs's Great-Man Theory of Technology," The Atlantic (August 16): n.p. http://www.theatlantic.com/entertainment/archive/2013/o8/-i-jobs-i-s-great-man -theory-of-technology/278720/.

Geertz, C. 1973. The Interpretation of Cultures (New York: Basic Books).

Geertz, C. 1980. Negara: The Theatre State in Nineteenth-Century Bali (Princeton: Princeton University Press).

Geertz, C. 1983. Local Knowledge: Further Essays in Interpretive Anthropology (New York: Basic Books).

Geertz, C. 2000. Available Light: Anthropological Reflections on Philosophical Topics (Princeton: Princeton University Press).

George, A.R. 2003. The Babylonian Gilgamesh Epic: Introduction, Criticial Edition, and Cuneiform Texts, 2 volumes (Oxford: Oxford University Press).

George, M.K. 2009. Israel's Tabernacle as Social Space (Ancient Israel and Its Literature, 2; Atlanta: Society of Biblical Literature).

Gilmour, R. 2016. "(Hi)story Telling in the Books of Samuel," in Fewell 2016:192-203.

Ginzburg, C. 1992. "Just One Witness: The Extermination of the Jews and the Principle of Reality," in Friedlander 1992: 82-96.

Goldstein, J. (ed.). 1994. Foucault and the Writing of History (Oxford: Blackwell).

Grabbe, L.L. 2007. Ancient Israel: What Do We Know and How Do We Know It? (London: T\&T Clark).

Green, A., and K. Troup (eds.). 1999. The Houses of History: A Critical Reader in TwentiethCentury History and Theory (New York: NYU Press).

Greenblatt, S. 1992. Marvelous Possessions: The Wonder of the New World (Chicago: University of Chicago Press).

Grethlein, J. 2013. Experience and Teleology in Ancient Historiography: "Futures Past" from Herodotus to Augustine (Cambridge: Cambridge University Press).

Gutting, G. 2007. "Zammito and the Kuhnian Revolution," History and Theory 46: 252-63.

Halpern, B. 1988. The First Historians: The Hebrew Bible and History (San Francisco: Harper \& Row).

Halpern, B. 2001. David's Secret Demons: Messiah, Murderer, Traitor, King (Grand Rapids, MI: Eerdmans). 
Halpern, B. 2010. "Archaeology, the Bible and History: The Fall of the House of Omriand the Origins of the Israelite State," in Levy 2010: 262-84.

Halpern, B. 2011. "David and the Historical Imagination: A Counterpoint in Evocation," in L.L. Grabbe (ed.), Enquire of the Former Age: Ancient Historiography and Writing the History of Israel (European Seminar in Historical Methodology, 9; Library of Hebrew Bible/Old Testament Studies, 554; New York: T\&T Clark): 210-14.

Halttunen, K. 1999. "Cultural History and the Challenge of Narrativity," in Bonnell and Hunt 1999: 165-81.

Hartog, F. 2015. Regimes of Historicity: Presentism and Experiences of Time (trans. S. Brown; New York: Columbia University Press [French original, 2003]).

Hawk, L.D. 2000. Joshua (Berit Olam; Collegeville, MN: Liturgical).

Hendel, R. 2005. Remembering Abraham: Culture, Memory, and History in the Hebrew Bible (New York: Oxford University Press).

Hendel, R. 2010. "Culture, Memory, and History: Reflections on Method in Biblical Studies," in Levy 2010: 250-61.

Hens-Piazza, G. 2002. The New Historicism (Guides to Biblical Scholarship: Old Testament Series; Minneapolis: Fortress).

Hobson, R. 2012. Transforming Literature into Scripture: Texts as Cult Objects at Nineveh and Qumran (Sheffield: Equinox).

Hunt, L. 1986. "French History in the Last Twenty Years: The Rise and Fall of the Annales Paradigm," Journal of Contemporary History 21: 209-24.

Hunt, L. (ed.). 1989. The New Cultural History (Berkeley: University of California Press). Hunt, L. 2014. Writing History in the Global Era (New York: Norton).

Iggers, G.G. 2002. "The Professionalization of Historical Studies and the Guiding Assumptions of Modern Historical Thought," in Kramer and Maza 2002: 225-42.

Iggers, G.G., and J.M. Powell (eds.). 1990. Leopold von Ranke and the Shaping of the Historical Discipline (Syracuse, NY: Syracuse University Press).

Jobling, D. 1998. 1 Samuel (Berit Olam; Collegeville, MN: Liturgical).

Joseph, A.L. 2015a. Portrait of the Kings: The Davidic Prototype in Deuteronomistic Poetics (Minneapolis: Fortress).

Joseph, A.L. 2015b. "Who Is like David? Was David like David? Good Kings in the Book of Kings," Catholic Biblical Quarterly 77: 20-41.

Kermode, F. 2003. The Sense of an Ending: Studies in the Theory of Fiction with a New Epilogue (Oxford: Oxford University Press).

Klancher, J. 1989. "English Romanticism and Cultural Production," in Veeser 1989: $77-88$.

Klein, K.L. 2011. From History to Theory (Berkeley: University of California Press).

Knauf, E.A. 2013. "Remembering Joshua," in Edelman and Ben Zvi 2013: 106-27.

Knauf, E.A. 2014. "Why 'Joshua'?” in Edelman 2014: 73-84. 
Knauf, E.A., and P. Guillaume. 2016. A History of Biblical Israel: The Fate of the Tribes and Kingdoms from Merenptah to Bar Kochba (Sheffield: Equinox).

Kramer, L.S. 1989. "Literature, Criticism, and Historical Imagination: The Literary Challenge of Hayden White and Dominick LaCapra," in Hunt 1989: 97-128.

Kramer, L., and S. Maza (eds.). 2002. A Companion to Western Historical Thought (Malden, MA: Blackwell).

Kratz, R.G. 2015. Historical \& Biblical Israel: The History, Tradition, and Archives of Israel and Judah (trans. P.M. Kurtz; Oxford: Oxford University Press).

Kuhn, T.S. 1996. The Sturcture of Scientific Revolutions (Chicago: University of Chicago Press, 3 d edn [original, 1962]).

Kuhrt, A. 1995. The Ancient Near East c. 3000-33o BC (London: Routledge).

Landy, F. 2012. "Notes Towards a Poetics of Memory in Ancient Israel," in E. Ben Zvi and C. Levin (eds.), Remembering and Forgetting in Early Second Temple Judah (Forschungen zum Alten Testament, 85; Tübingen: Mohr Siebeck): 331-45.

LeMon, J.M., and K.H. Richards (eds.). 2009. Method Matters: Essays on the Interpretation of the Hebrew Bible in Honor of David L. Peterson (Resources for Biblical Study, 56; Atlanta: Society of Biblical Literature).

Leonard-Fleckman, M. 2016. The House of David: Between Political Formation and Literary Revision (Minneapolis: Fortress).

Levenson, J.D. 1997. Esther: A Commentary (Old Testament Library; Louisville, KY: Westminster John Knox).

Levy, T.E. (ed.). 2010. Historical Biblical Archaeology and the Future: The New Pragmatism (London: Equinox).

Maza, S. 2004. "Stephen Greenblatt, New Historicism, and Cultural History, or, What We Talk about When We Talk about Interdisciplinarity," Modern Intellectual History 1: 249-65.

Mazlish, B. 2003. "Empiricism and History," Historically Speaking 4.3: 12-14.

Megill, A. 1987. "The Reception of Foucault by Historians," Journal of the History of Ideas 48: 117-41.

Megill, A. 2007. Historical Knowledge, Historical Error: A Contemporary Guide to Practice (Chicago: University of Chicago Press).

Milstein, S.J. 2016. Tracking the Master Scribe: Revision through Introduction in Biblical and Mesopotamian Literature (New York: Oxford University Press).

Misztal, B.A. 2003. Theories of Social Remembering (Maidenhead, UK: Open University Press).

Momigliano, A. 2016. "The Rules of the Game in the Study of Ancient History" (trans. K.W. Yu), History and Theory 55: 39-45.

Moore, M.B. 2006. Philosophy and Practice in Writing a History of Ancient Israel (Library of Hebrew Bible/Old Testament Studies, 435; New York: T\&T Clark). 
Moore, M.B., and B.E. Kelle. 2011. Biblical History and Israel's Past: The Changing Study of the Bible and History (Grand Rapids, MI: Eerdmans).

Moyn, S. 2015. "New Old Things," The Nation (February 9): 27-32.

Mullen, E.T., Jr. 1993. Narrative History and Ethnic Boundaries: The Deuteronomistic Historian and the Creation of Israelite National Identity (Atlanta: Scholars Press).

Na'aman, N. 1994. “The 'Conquest of Canaan' in the Book of Joshua and in History," in I. Finkelstein and N. Na'aman (eds.), From Nomadism to Monarchy: Archaeological and Historical Aspects of Early Israel (Jerusalem: Israel Exploration Society): 218-81.

Nandy, A. 1997. "History's Forgotten Doubles," History and Theory 34: 44-66.

Nelson, J.S. 1975. Review Essay of Metahistory by Hayden White, History and Theory 14: 74-91.

Nelson, R.D. 1997. Joshua: A Commentary (Old Testament Library; Louisville, KY: Westminster John Knox).

Newsom, C.A. 2006. "Rhyme and Reason: The Historical Résumé in Israelite and Early Jewish Thought," in A. Lemaire (ed.), Congress Volume Leiden 2004 (Vetus Testamentum Supplements, 109; Leiden: Brill): 215-33.

Newsom, C.A. 2009. "Reflections on Ideological Criticism and Postcritical Perspectives," in LeMon and Richards 2009: 541-59.

Newsom, C.A. 2010. "Contemporary Methods in Biblical Study," in M.D. Coogan (ed.), The New Oxford Annotated Bible (New York: Oxford University Press, fully revised 4th edn): 2227-34.

Nichanian, M. 2009. The Historiographic Perversion (trans., with afterword, G. Anidjar; New York: Columbia University Press [French original, 2006]).

Nissinen, M. 2009. "Reflections on the 'Historical-Critical' Method: Historical Criticism and Critical Historicism," in LeMon and Richards 2009: 479-504.

Noll, K.L. Canaan and Israel in Antiquity: A Textbook on History and Religion (London: Bloomsbury, 2d edn).

Nora, P. 1989. "Between Memory and History," Representations 26: 7-24.

Noth, M. 1958. The History of Israel (trans. S. Godman; New York: Harper).

Novick, P. 1988. That Noble Dream: The "Objectivity Question" and the American Historical Profession (Cambridge: Cambridge University Press).

O’Brien, P. 1989. "Michel Foucault's History of Culture," in Hunt 1989: 25-46.

Olick, J.K. 2007. The Politics of Regret: On Collective Memory and Historical Responsibility (New York: Routledge).

Olick, J.K., and J. Robbins. 1998. "Social Memory Studies: From 'Collective Memory' to the Historical Sociology of Mnemonic Practices," Annual Review of Sociology 24: 105-40.

Ortner, S.B. (ed.). 1997. “The Fate of 'Culture': Geertz and Beyond," Representations 59, Special Issue. 
Partner, N. 2009. "Narrative Persistence: The Post-Postmodern Life of Narrative Theory," in Ankersmit et al. 2009: 81-104.

Partner, N. 2016. "Foucault's Iconic Afterlife: The Posthumous Reach of Words and Things," History and Theory, Theme Issue 54: 35-53.

Partner, N., and S. Foot (eds.). 2013. The SAGE Handbook of Historical Theory (London: Sage).

Paul, H. 2011. Hayden White: The Historical Imagination (Cambridge: Polity).

Person, R.F., Jr. 2016. "Biblical Historiography as Traditional History," in Fewell 2016: $73-83$.

Pioske, D.D. 2015a. David's Jerusalem: Between Memory and History (Routledge Studies in Religion, 45; New York: Routledge).

Pioske, D.D. 2015b. "Retracing a Remembered Past: Methodological Remarks on Memory, History, and the Hebrew Bible," Biblical Interpretation 23: 291-315.

Pioske, D.D. Forthcoming 2018. Memory in a Time of Prose: Studies in Hebrew Scribalism, Epistemology, and the Biblical Past (New York: Oxford University Press).

Pitcher, L. 2009. Writing Ancient History: An Introduction to Classical Historiography (London: I. B. Tauris).

Pollock, S. 2006. The Language of the Gods in the World of Men: Sanskrit, Culture, and Power in Premodern India (Berkeley: University of California Press).

Provan, I., V.P. Long, and T. Longman III. 2015. A Biblical History of Israel (Louisville, KY: Westminster John Knox, 2d edn).

Ricoeur, P. 1984-1988. Time and Narrative, 3 volumes (trans. K. McLaughlin and D. Pellauer; Chicago: University of Chicago Press).

Ricoeur, P. 2004. Memory, History, Forgetting (trans. K. Blamey and D. Pellauer; Chicago: University of Chicago Press).

Rigney, A. 2013. "History as Text: Narrative Theory and History," in Partner and Foot 2013: 183-201.

Rom-Shiloni, D. 2016. "Hebrew Bible Theology: A Jewish Descriptive Approach," Journal of Religion 96: $165^{-84}$.

Rorty, R.M. (ed.). 1992. The Linguistic Turn: Essays in Philosophical Method (Chicago: University of Chicago Press).

Rowlett, L.L. 1996. Joshua and the Rhetoric of Violence: A New Historicist Analysis (Journal for the Study of the Old Testament Supplement Series, 226; Sheffield: Sheffield Academic Press).

Russell, S. 2016. "Space, Land, Territory, and the Study of the Bible," Brill Research Perspectives in Biblical Interpretation 1.4.

Sahlins, M.D. 1985. Islands of History (Chicago: University of Chicago Press).

Said, E.W. 2000. "Invention, Memory, and Place," Critical Inquiry 26: 175-92.

Satlow, M.L. 2014. How the Bible Became Holy (New Haven, CT: Yale University Press). 
Schmid, K. 2012. The Old Testament: A Literary History (trans. L.M. Maloney; Minneapolis: Fortress).

Schwartz, B. 1998. "Frame Images: Towards a Semiotics of Collective Memory," Semiotica 121:1-40.

Schwartz, B. 2000. Abraham Lincoln and the Forge of National Memory (Chicago: University of Chicago Press).

Schwartz, B. 2008. Abraham Lincoln in the Post-Heroic Era: History and Memory in Late Twentieth-Century America (Chicago: University of Chicago Press).

Sewell, W.H., Jr. 1999. "The Concept(s) of Culture," in Bonnell and Hunt 1999: 35-61.

Sommer, B.D. 2011. "Dating Pentateuchal Texts and the Perils of Pseudo-Historicism," in T.B. Dozeman, K. Schmid, and B.J. Schwartz (eds.), The Pentateuch: International Perspectives on Current Research (Forschungen zum Alten Testament, 78; Tübingen: Mohr Siebeck): 85-108.

Spiegel, G.M. (ed.). 2005. Practicing History: New Directions in Historical Writing after the Linguistic Turn (New York: Routledge).

Stone, L.G. 2014. "Early Israel and Its Appearance in Canaan," in Arnold and Hess 2014: 127-64.

Thompson, T.L. 1999. The Mythic Past: Biblical Archaeology and the Myth of Israel (New York: Basic Books).

Turner, V. 1969. The Ritual Process: Structure and Anti-Structure (Chicago: Aldine).

Van Seters, J. 1992. Prologue to History: The Yahwist as Historian in Genesis (Louisville, KY: Westminster John Knox).

Van Seters, J. 2009. The Biblical Saga of King David (Winona Lake, IN: Eisenbrauns).

Vann, R.T. 2009. "Hayden White, Historian," in Ankersmit et al. 2009: 304-31.

Veeser, H.A. (ed.). 1989. The New Historicism (New York: Routledge).

Von Rad, G. 1966. "The Beginnings of Historical Writing in Ancient Israel," in The Problem of the Hexateuch: And Other Essays (trans. E.W. Trueman Dicken; London: Oliver \& Boyd): 166-204.

Wellhausen, J. 1957. Prolegomena to the History of Israel (Edinburgh: Black, 1885 [German original, 1883]; reprint, Cleveland: Meridian).

Wertsch, J.V. 2009a. "Collective Memory," in Boyer and Wertsch 2009: 117-37.

Wertsch, J.V. 20ogb. “Collective Remembering," Semiotica 173: 233-47.

Wertsch, J.V. 2010. "Text and Dialogism in the Study of Collective Memory," in K. Junefelt and P. Nordin (eds.), Proceedings from the Second International Interdisciplinary Conference on Perspectives and Limits of Dialogism in Mikhail Bakhtin, Stockholm University, Sweden, June 3-5, 2009 (Stockholm: Stockholm University): 33-38. http:// www.nordiska.su.se/bakhtin2009 (accessed 18 July 2017).

White, H. 1973. Metahistory: The Historical Imagination in Nineteenth-Century Europe (Baltimore: Johns Hopkins University Press). 
White, H. 1978. Tropics of Discourse: Essays in Cultural Criticism (Baltimore: Johns Hopkins University Press).

White, H.1987. The Content of the Form: Narrative Discourse and Historical Representation (Baltimore: Johns Hopkins University Press).

White, H. 2010. The Fiction of Narrative: Essays on History, Literature, and Theory, 1957-2007 (ed. and with an introduction by R. Doran; Baltimore: Johns Hopkins University Press).

White, H. 2014. The Practical Past (Evanston, IL: Northwestern University Press).

Williams, R. 2011. "BTB Readers' Guide: Social Memory." Biblical Theology Bulletin 41: 189-200.

Wilson, I.D. 2013. "Conquest and Form: Narrativity in Joshua $5^{-11}$ and Historical Discourse in Ancient Judah," Harvard Theological Review 106: 309-29.

Wilson, I.D. 2014. "Joseph, Jehoiachin, and Cyrus: On Book Endings, Exoduses and Exiles, and Yehudite/Judean Social Remembering," Zeitschrift für die alttestamentliche Wissenschaft 126: 521-34.

Wilson, I.D. 2016. "Yahweh's Consciousness: Isaiah 40-48 and Ancient Judean Historical Thought," Vetus Testamentum 66: 646-61.

Wilson, I.D. 2017. Kingship and Memory in Ancient Judah (New York: Oxford University Press).

Workman, T. 2015. "Thucydides, Science, and Late Modern Philosophy," in C. Lee and N. Morley (eds.), A Handbook to the Reception of Thucydides (Chichester: Wiley Blackwell): 512-28.

Wright, J.L. 2014. David, King of Israel, and Caleb in Biblical Memory (Cambridge: Cambridge University Press).

Younger, K.L., Jr. 1990. Ancient Conquest Accounts: A Study in Ancient Near Eastern and Biblical History Writing (Journal for the Study of the Old Testament Supplement Series, 98; Sheffield: Sheffield Academic Press).

Zammito, J.H. 2004. A Nice Derangement of Epistemes: Post-positivism in the Study of Science from Quine to Latour (Chicago: University of Chicago Press). 